PNL-7530

UC.602

3

\title{
Evaluation of Experimental Factors that Influence the Application and Discrimination Capability of the Product Consistency Test
}

J. W. Shade

G. F. Piepel

June 1991

Prepared for the U.S. Department of Energy under Contract DE-AC06-76RLO 1830

Pacific Northwest Laboratory

Operated for the U.S. Department of Energy by Battelle Memorial Institute 


\title{
DISCLAIMER
}

This report was prepared as an account of work sponsored by an agency of the United States Government. Neither the United States Government nor any agency thereof, nor Battelle Memorial Institute, nor any of their employees, makes any warranty, expressed or implied, or assumes any legal liability or responsibility for the accuracy, completeness, or usefulness of any information, apparatus, product, or process disclosed, or represents that its use would not infringe privately owned rights. Reíerence herein to any specific commercial product, process, or service by trade name, trademark, manulacturer, or otherwise does not necessarily constitute or imply its endorsement, recommendation, or favor $\mathrm{ng}$ by the United States Government or any agency thereof, or Battelle Memorial Institute. The views and opinions of authors expressed herein do not necessarily state or reflect those of the United Siates Government or any agency thereof.

\author{
PACIFIC NORTHWEST LABORATORY \\ operated by \\ BATTELLE MEMORIAL INSTITIJTE \\ for the \\ UNITED STATES DEPARTMENT OF ENERGY \\ under Contract DE-ACO6-76RLO 1830
}

Printed in the United States of America

Available to DOE and DOE contractors from the

Office of Scientific and Technical Information, P.O. Box 6.2, Oak Ridge, TN 37831; prices available írom (615) 576-8401. FTS 626-8401.

Available to the public from the National Technical Information Service, U.S. Depariment of Commerce, 52 H5 Port Royal Rd., Springrield, VA 22161. 
EVALUATION OF EXPERIMENTAL FACTORS THAT INFLUENCE THE APPLICATION AND DISCRIMINATION CAPABILITY OF THE PRODUCT CONSISTENCY TEST

3. W. Shade

G. F. Piepel

June 1991

Prepared for the U.S. Department of Energy under Contract DE-ACO6-76RLO 1830

Pacific Northwest Laboratory

Richland, Washington 99352 



\section{SUMMARY}

An experiment was performed to investigate the effects (on $\mathrm{pH}$ and elemental releases of $\mathrm{Al}, \mathrm{Fe}, \mathrm{K}, \mathrm{Na}, \mathrm{Si}, \mathrm{B}, \mathrm{Li}$, and $\mathrm{Mn}$ ) of modifications to the test conditions of the Product Consistency Test (PCT). The experiment was replicated three times; each replicate involved leach testing two glasses with each of 24 different sets of PCT conditions. The 24 sets of test conditions consist of all combinations of the levels of four factors:

\section{Factor}

Test duration

Surface area/volume (A/V)

Cleaning

Fi]tering
Leve1s

3 and 7 days

5,10 , and $100 \mathrm{~mL} / \mathrm{g}$

with and without

$0.45 \mu \pi$ and without

The two glasses used in the testing were provided by Savannah River Laboratory (SRL) and are denoted SRL-202-G and SRL-202-P. The two glasses are similar in composition, with SRL-202-P designed to be less durable than SRL-202-G.

The experimental data were statistically analyzed to assess the individual and interaction effects of the four factors on 1) the $\mathrm{pH}$ and elemental release results, 2) the precision of the $\mathrm{pH}$ and elemental release results, and 3) the ability to discriminate between SRL-202-G and SRL-202-P based on $\mathrm{pH}$ and elemental releases. The following conclusions were reached in each of these three areas:

1. Al1 four factors significantly affect (either individually or in interactions) $\mathrm{pH}$ and the elemental releases, with a few exceptions.

2. None of the four factors significantly affect (either individually or in interactions) the precision of $\mathrm{pH}$ results, while all four factors significantly affect elemental release results. $A / V$ and filtering have the most important effects on the precision of elemental releases.

3. Oniy a few factors were found to have significant individual or interaction effects on the ability to discriminate, and the findings were not always consistent from one element to the next. This 
may be due to the small number of replicates and the effects of the factors in "separating" SRL-202-G and SRL-202-P cancelling the effects of the factors on precision. However, there was evidence (although not always statistically significant) that $A / V$ and filtering affect the ability to discriminate. The ability to discriminate was better for tests with larger $A / V$ values and filtered leachates. There was also an indication that "not cleaning" the crushed glass samples prior to leaching may improve the ability to discriminate for some elements.

The following sets of PCT conditions were determined to provide the "best" ability to discriminate among all the sets, given that they discriminated between SRL-202-G and SRL-202-P for eight or all nine of the responses (i.e., $\mathrm{pH}$ and the eight elemental releases):

$\begin{array}{cccc}\begin{array}{c}\text { Test Duration } \\ \text { (days) }\end{array} & \begin{array}{c}\text { A/V } \\ (\mathrm{mL} / \mathrm{g})\end{array} & \begin{array}{c}\text { Cleaning } \\ \text { (y or } n)\end{array} & \begin{array}{c}\text { Filtering } \\ (y \text { or } n)\end{array} \\ 3 & 5 & n & y \\ 3 & 5 & y & y \\ 7 & 5 & n & y \\ 7 & 5 & y & y \\ 7 & 10 & n & y\end{array}$

It was also concluded that long-term (replicate-to-replicate) variation in PCT results is significantly larger than the short-term (within replicate) variation for $\mathrm{pH}$ and several elemental releases. For the sets of test conditions providing the best ability to discriminate, precisions (including short-term and long-term variation) quantified in terms of percent relative standard deviations were in the 0.5 to $1.5 \%$ range for $\mathrm{pH}$, in the 5 to $10 \%$ range for elemental releases having better precisions, and in the 12 to $30 \%$ range for elemental releases having poorer precisions. (These percent relative standard deviations do not include variations due to crushing, sieving, and cleaning glass samples.) 


\section{CONTENTS}

SUMMARY ...............................

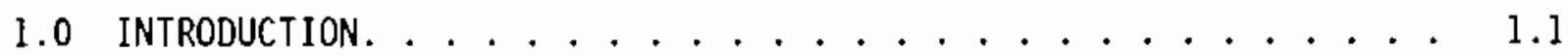

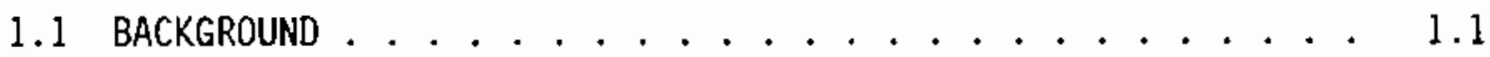

1.2 PURPOSE AND SCOPE . . . . . . . . . . . . 1.2

2.0 EXPERIMENTAL FACTORS AND POSSIBLE EFFECTS . . . . . . . . 2.1

2.1 EXPERIMENTAL FACTORS AND LEVELS INVESTIGATEO . . . . . 2.1

2.2 POSSIBLE EFFECTS OF THE EXPERIMENTAL FACTORS . . . . . . 2.1

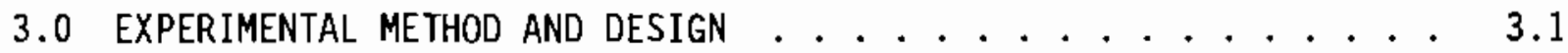

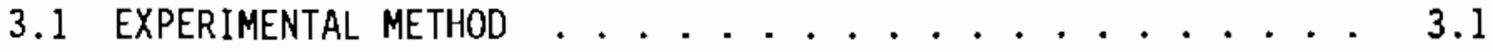

3.2 EXPERIMENTAL DESIGN $\ldots \ldots \ldots \ldots . \ldots . \ldots . \ldots . \ldots$

4.0 STATISTICAL ANALYSES OF THE DATA ................ 4.1

4.1 MEANS. STANDARD DEVIATIONS, AND \%RSDS .............. 4.1

4.2 EFFECTS OF THE EXPERIMENTAL FACTORS ON pH

4.3 EFFECTS OF THE EXPERIMENTAL FACTDRS ON

4.4 EFFECTS OF THE EXPERIMENTAL FACTORS ON

THE ABILITY TO DISCRIMINATE . . . . . . . . . . . . 4.12

4.5 THE "BEST" SETS OF TEST CONDITIONS FOR THE PCT . . . . . . 4.14

5.0 CONCLUSIONS . . . . . . . . . . . . . . . . 5.1

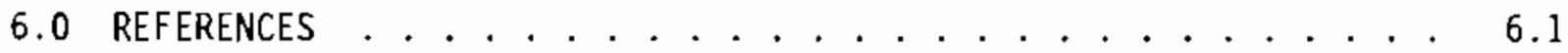

APPENDIX A - ELEMENTAL RELEASE DATA FOR THE THREE REPLICATES . . . . A.1

APPENDIX B - SUPPLEMENTARY 5 DAY AND 18A DATA FOR SRL-202-G

AND SRL-202-P GLASS . . . . . . . . . . . B. 


\section{FIGURES}

4.1 Illustration of the $T \star C \star F$ Interaction Effect on $\mathrm{Na}$

Concentration

\section{$\underline{\text { TABLES }}$}

2.1 Experimental Factors and Their Levels ............. 2.1

3.1 Nominal Composition of SRL-202-G and SRL-202-P Glasses. . . . . 3.2

3.2 Test Matrix for the PCT Modification Evaluation with SRL-202-G and SRL-202-P GTasses . . . . . . . . . . 3.4

4.1 Means, SDS, and \%RSDs from the PCT Experiment on Glasses SRL-202-G and SRL-202-P . . . . . . . . . . 4.2

4.2 Minimum, Median and Maximum \%RSDs Over the 24 Test Conditions Investigated in the PCT Experiment . . . . . . 4.6

4.3 Factors on $\mathrm{pH}$ and Elemental Releases. . . . . . . . . . . 4.7

4.4 Statistically Significant Factor Effects Found in the ANOVAs Performed on the $\mathrm{pH}$ and Elemental Release Data from the PCT Experiment

4.5 Statistically Significant Factor Effects Found in the ANOVAs Performed on Log (Variances) of the $\mathrm{pH}$ and Elemental Release Data from the PCT Experiment. . . . . . . . 4.11

4.6 T-Ratio for Discriminating Between SRL-202-G and SRL-202-P for Each of 24 Sets of PCT Conditions Investigated in the PCT Experiment. . . . . . . . . . . . . . 4.13

4.7 Statistically Significant Factor Effects Found in the ANOVAs Performed on t-Ratios of the pH and Elemental Release Data from the PCT Experiment . . . . . . . . . . . . . . 4.15

4.8 Means of t-Ratios for Each Level of Each Factor . . . . . . . . 4.15

$4.9 \%$ RSDs Pooled over SRL-202-G and SRL-202-P for the Five Best Discrimination Sets of PCT Conditions . . . . . . . . 4.17 


\subsection{INTRODUCTION}

It is desirable to have a means of monitoring possible changes in waste glass durability during production so that the product remains within acceptable limits. A leach test called the Product Consistency Test (PCT) was developed by Savannah River Laboratory (SRL) as such a production test for the Defense Waste Processing Facility (DWPF). This report examines some of the experimental factors that may be used in the PCT that could influence test precision and its ability to function as intended.

\subsection{BACKGROUND}

The PCT is a powder leach test that was developed to provide a simple and rapid procedure for monitoring possible variations of composition and homogeneity of DWPF glass during production. To function as intended, the PCT must be able to distinguish between glasses that may have different durabilities based on repository acceptance testing of 28-days duration, yet be able to make this distinction within a few days while the glasses are being produced. Preferably the test duration should not be longer than 5 to 7 days, but less than 3 days would be even more desirable. There must be a high degree of precision associated with the test so that leaching effects associated with small differences in composition and homogeneity can be distinguished because these properties are the major contributors to glass durability. The test must also be relatively easy to apply in a hot cell environment.

The Waste Acceptance Preliminary Specification 1.3 (WAPS) requires that the DWPF demonstrate control of radionuclide release properties of the final waste form during production. In addition, it is the responsibility of the DWPF to show that the results of the production control test can be related to site-specific release tests or else these tests must be conducted separately. Site-specific tests are usually conducted for a month or more, are rock-water dominated rather than waste form dominated, and include tests at elevated pressure. Consequently, they are not easily adapted to a production test. Furthermore, the current waste acceptance criteria for the Nevada Nuclear Waste Storage Investigations (NNWSI) Project require an elemental 
mass loss not to exceed $1 \mathrm{~g} / \mathrm{m}^{2}-\mathrm{d}$ in a 28 -day MCC-1 test. Since 28 days is too long for a reasonable production test, the PCT must be demonstrated as a good predictor of the acceptance criteria. For a given $\mathrm{pH}$, the normalized release rate relationship between crushed glass and glass monoliths has been shown to be a continuous function of surface area/volume times time $[(A / V) \times t]$ (Pederson et a1. 1983). In view of these considerations, Jantzen and Bibler (1987) adapted a crushed glass type of leach test as the basis for the PCT.

The PCT developed by Jantzen and Bibler (1987) is based on a modified version of the Materials Charaterization Center (ACC) MCC-3 test. Other tests that use crushed glass, including ASTM D33987-81 and a Corning Glass Horks test, were also reviewed for possible use. The modified version of the MCC-3 test protocol included shorter time periods, one sieve size fraction, and uncleaned glass samples, but conceptually was very similar to the original MCC-3 protocol. The feasibility of the PCT was demonstrated by a round robin test conducted internally by SRL in 1987 using glasses representing a wide range of compositions and durability (Jantzen and Bibler 1987). These results did not provide a lab-to-lab comparison or permit discrimination between glasses of similar composition. Subsequently a second PCT round robin was conducted by the ACC (Piepel et al. 1989) that involved seven laboratories and four glasses, two of which were supplied by SRL. The second round robin provided information on interlab comparison and the abjlity to discriminate between glasses of similar composition.

\subsection{PURPOSE AND SCOPE}

The purpose of the present work was to examine other factors that may affect the discrimination ability of the PCT protocol. These factors include sample preparation, leachate filtration, ratio of sample surface area to leachant volume, and test duration. This effort is intended as a screening effort. Sample cleaning and leachate filtration, for example, would require additional hot cell procedures that may or may not be warranted by the amount of increase in discrimination resolution. 
It was intended that a subsequent study would be conducted to focus on methods of improving test precision and to show how PCT results for a given glass predict the 28 -day $M C C-1$ test results while maintaining satisfactory discrimination ability. Identifying and eliminating factors that might mask results or cause analytical interference should improve precision. It is also expected that an acceptable functional relationship that shows how PCT results for a given glass predict the 28-day MCC-1 test results will be determined. The follow-up study will also investigate the use of short-term methods such as $\mathrm{pH}-$ stat measurements as a discrimination tool and explore the use of geochemical codes to evaluate reaction paths in both PCT and MCC-1 tests to help demonstrate convergence of results. Only the results of the screening study are reported here. 



\subsection{EXPERIMENTAL FACTORS AND POSSIBLE EFFECTS}

The initial portion of the PCT experimental factor evaluation was designed as a screening experiment to identify and prioritize factors that might improve or detract from the intended function of the test. These factors, the levels (i.e., values) at which they were investigated, and their possible effects on PCT sensitivity are discussed below.

\subsection{EXPERIMENTAL FACTORS AND LEVELS INVESTIGATED}

The selection of experimental factors for investigation was based partiy on previous experience of waste glass leach testing and partly on an interest in those factors that would simplify the test if they could be eliminated. Only two glass compositions were used. These glasses were supplied by SRL and are designated SRL-202-G and SRL-202-P. All testing was conducted at $90^{\circ} \mathrm{C}$ in deionized water using one size fraction $(-100+200$ mesh). The factors evaluated were test duration, sample surface area-to-volume ratio ( $A / \mathrm{V}$, in terms of leachate volume per gram of crushed sample, $\mathrm{mL} / \mathrm{g}$ ), cleaning the glass after crushing, and filtering the leachates through $0.45-\mu \mathrm{m}$ filters. The list of factors and their levels are shown in Table 2.1.

\subsection{POSSIBLE EFFECTS OF THE EXPERIMENTAL FACTORS}

Fine-grained particles in the micron to submicron size range are formed during the sample preparation process and become electrostaticaliy attached to sample surfaces. Because of their small size, these particles contribute excess surface free energy and rapidly dissolve during the initial stages of

\section{TABLE 2.1. Experimental Factors and Their Leve]s}

\begin{tabular}{lll}
\multicolumn{1}{c}{ Factor } & & Levels \\
\cline { 1 - 1 } Test duration & & 3 and 7 days \\
A/V & & 5,10, and $100 \mathrm{~mL} / \mathrm{g}$ \\
Filtering & & 0.45 m and without \\
Cleaning & & with and without
\end{tabular}


glass leaching. Usually they are completely dissolved within the first 24 hours. There are several ways in which the fines might affect test results. If unequal amounts and distributions of fines on different glasses exist, differences in leachate compositions will occur that are related to fines differences rather than to compositional differences among glasses. Rapid dissolution of fines might result in an abrupt $\mathrm{pH}$ change that enhances the leaching of the bulk glass so that it appears less durable. If a nonhomogeneous glass is tested, the composition of fines may be different from that of the bulk glass. In this case, test results will be biased in favor of material contributed by the fines. In order to evaluate the effects of the presence of fines, half of the $-100+200$ mesh fraction of each glass was cleaned, and the other half was used in the as-crushed condition without cleaning.

As indicated above, testing was conducted for two test durations, 3 and 7 days, with $A / V$ ratios of 5,10 , and $100 \mathrm{~mL} / \mathrm{g}$. Decreasing the volume-tomass ratio (equivalent to increasing the specimen surface area to leachant volume ratio) may enhance the ability of the test to discriminate at short time periods. Also, the use of a variable $A / V \times$ time function will permit a correlation with the $\mathrm{MCC}-1$ repository acceptance test. The $A / V$ ratio for the MCC-1 test is $0.1 \mathrm{~cm}^{-1}$, so a 28 -day test will have an $\mathrm{A} / \mathrm{V} \times$ time function of $2.8 \mathrm{~cm}^{-1}-\mathrm{d}$. The $-100+200$ mesh size fraction used in the PCT test has a nominal specific surface area of about $180 \mathrm{~cm}^{2} / \mathrm{g}$, so an $A / \mathrm{V}$ ratio of $100 \mathrm{~mL} / \mathrm{g}$ would yieid an $A / V \times$ time function of $1.8 \mathrm{~cm}^{-1}-\mathrm{d}$; the next highest ratio would be $18.0 \mathrm{~cm}^{-1}-\mathrm{d}$. The usefulness of this relationship as a possible predictor of MCC-1 test results will be investigated in a subsequent study, but some initial observations of the effects of time and $A / V$ ratios are made in this report.

Several types of particulates can occur in leachates; therefore, the effects of filtering may be important. Suspended particulates and colloids may occur in leachates, particularly those from tests at high $A / V$ ratios; more scatter (that is, less precision) in leachate analytical results will be expected from unfiltered samples than from filtered samples. Also, solid glass samples may be inadvertantly included during the pipetting process of obtaining the leachate sample after a test. Lower $A / V$ ratio tests may not 
require filtration if leachate concentrations are low, and if this type of test is still able to discriminate satisfactorily between glasses, the PCT protocol could be simplified.

Filtering may have an effect on the precision of some elements, but not others. The concentrations of eight elements, Al, Fe, Mn, K, Na, Li, Si, and $B$, plus $\mathrm{pH}$ were determined in the Teachates. Presumably those elements that remain in true solution and do not readily form precipitates or colloid particles would be the best choice to use for discriminating between glasses. At high $\mathrm{pH}$ values that are typical of waste glass leachates, $\mathrm{Al}, \mathrm{Fe}$, and $\mathrm{Mn}$ can form precipitates with low solublity; $B, L i$, and $\mathrm{Na}$ are usually undersaturated. $K$ analyses are considered less reliable than $\mathrm{Na}$, but $\mathrm{K}$ should behave in a manner similar to $\mathrm{Na}$. The solubility of $\mathrm{Si}$ is often controlled by amorphous silica saturation, which is $\mathrm{pH}$ dependent. Under the test conditions used in this report, Si may be present in colloidal forms or particulates at the higher $A / V$ ratios. If precipitation might interfere with PCT discrimination ability, low $A / V$ ratios should help reduce this type of interference. 



\subsection{EXPERIMENTAL METHOD AND DESIGN}

A brief description of the glass samples used and the modification to the PCT method as required to evaluate the selected experimental factors are presented here. This section also includes a description of the experimental design.

\subsection{EXPERIMENTAL METHOD}

Two glass samples, about $500 \mathrm{~g}$ each, labeled SRL-202-G and SRL-202-P were received from SRL as frit with particles varying from a few millimeters to about $2 \mathrm{~cm}$ in size. These $\mathrm{glasses}$ represent a second batch prepared by Corning Glass Works. They are similar to, but not the same composition as, the two SRL-provided glasses that were previously used in the PCT round robin (Piepel et al. 1989). The nominal compositions of the glasses used in this study are given in Table 3.1. The MCC did not analyze these glasses.

A portion of each of these glasses was crushed and sieved so that a sufficient amount of material in the $-100+200$ mesh size range was obtained to complete the test matrix in triplicate. The glass was crushed using a tungsten carbide disk mill until the entire crushed material passed through a 100 mesh sieve. The material retained on the 200 mesh sieve was then used in the tests. Stainless steel sieves were used throughout. About half of the $-100+200$ mesh material for each glass was cleaned in the following manner. Approximately $50-\mathrm{g}$ samples were $\mathrm{placed}$ in a beaker along with deionized water equal to about 3 volumes of the glass. The beaker and contents were ultrasonically cleaned for about 30 seconds and then the liquid was decanted. This procedure was repeated 2 or 3 times until the liquid appeared clear. After decanting the last of the water, fresh absolute ethanol was added to the glass and the ethanol-glass mixture was ultrasonically cleaned for about a minute. The cleaned glass was air dried for 24 hours. Individual $50-\mathrm{g}$ aliquots of cleaned and dried samples of the same glass were then combined and used as starting materials for the test matrix. 
IABLE 3.1. Nominal Composition of SRL-202-G and SRL-202-P Glasses (wt\%)

$\begin{array}{lrr}\text { Oxide } & \text { SRL-202-G } & \frac{\text { SRL-202-P }}{\mathrm{Al}_{2} \mathrm{O}_{3}} \\ \mathrm{~B}_{2} \mathrm{O}_{3} & 5.15 & 4.78 \\ \mathrm{BaO} & 7.81 & 9.72 \\ \mathrm{CaO} & 0.16 & 0.22 \\ \mathrm{Cr}_{2} \mathrm{O}_{3} & 1.38 & 1.27 \\ \mathrm{CuO} & 0.11 & 0.10 \\ \mathrm{Fe}_{2} \mathrm{O}_{3} & 0.43 & 0.74 \\ \mathrm{~K}_{2} \mathrm{O} & 13.62 & 2.60 \\ \mathrm{Li}_{2} \mathrm{O} & 3.78 & 6.76 \\ \mathrm{MgO} & 4.31 & 3.91 \\ \mathrm{MnO} & 1.34 & 1.22 \\ \mathrm{Na}_{2} \mathrm{O} & 2.23 & 2.06 \\ \mathrm{NiO} & 9.41 & 10.22 \\ \mathrm{SiO}_{2} & 0.82 & 0.77 \\ \mathrm{TiO}_{2} & 48.65 & 44.19 \\ & 0.70 & 1.28 \\ & 100.00 & 100.00\end{array}$

The crushing, sieving, and cleaning of the two glasses was completed prior to the initiation of leach testing. Because these operations were performed only once prior to leach testing and not separateiy for each of the three replicates, the PCT experimental results co not contain information on the variation due to these operations. This makes it easier to statistically assess the effect of varying the factors studiec in the experiment, but does not provide for quantifying the contributions of these operations to PCT imprecision. It is expected that the crushing, sjeving, and cleaning steps of the PCT procedure are major contributors to F'CT variation and uncertainty.

Each of the two glasses was tested using the PCT protocol described by Jantzen and Bibler (1987) except for modifications related to the factors under investigation. The modifications includec two test durations, 3 and 7 days, the use of cleaned glass, and the use of some unfiltered leachate samples. The tests were conducted at $90^{\circ} \mathrm{C}$ in deionized water using Tefion 
PFA leach containers. After the test, an aliquot of leachate was pipetted into a small polyethylene beaker for $\mathrm{pH}$ determination, then the remaining leachate was extracted for analysis. If the sample was to be filtered, the filter used was a sterile $0.45-\mu \mathrm{m}$ syringe filter. Only cations were anaiyzed, so all leachate specimens were stabilized by adding an amount of concentrated $\mathrm{HNO}_{3}$ equal to $1 \%$ of the specimen volume. There was no attempt to randomize either leach containers or analytical samples. The tests were conducted in triplicate at three separate times over a $21 / 2$-month period.

\subsection{EXPERIMENTAL DESIGN}

The approach used to develop a test matrix for this study involved identifying and prioritizing specific objectives, and then statistically designing a test matrix that would provide adequate data to address these particuiar objectives without restrictive or arbitrary assumptions. The test matrix, presented in Table 3.2, represents only a small fraction of the possible sets of test conditions that would have been studied. A logical experimental strategy would be to 1) run the test matrix presented in Table 3.2, 2) statistically analyze and interpret the results, and then 3 ) use the results for guidance in determining whether additional tests are needed, and if so, what additional test conditions should be included.

The test matrix shown in Table 3.2 investigates the effects of four factors having $2,3,2$ and 2 levels (see Table 2.1), so that a total of 24 sets of test conditions are investigated $(2 \times 3 \times 2 \times 2=24)$. The test matrix was performed on the SRL-202-G and SRL-202-P glasses; "glass" can be considered another factor having two levels (hence, there are $48 \mathrm{glass}$ and test condition combinations). The 24 sets of conditions applied to the two glasses were replicated three times over a time period of $21 / 2$ months.

The PCT can be classified as a $2 \times 3 \times 2 \times 2 \times 2$ factorial experiment carried out in randomized complete blocks (Montgomery 1976). The three replicates are referred to in statistical jargon as "blocks," and they are "complete" because the whole test matrix was performed on both glasses for each replicate. Idealiy, "randomized" means that the tests within a block are set up, run, and the leachates analyzed in a random order. The tests 
IABLE 3.2. Test Matrix for the PCT Modification Evaluation with SRL-202-G and SRL-202-P Glasses

\begin{tabular}{|c|c|c|c|c|}
\hline$\underline{\text { Run ID }}$ & $\begin{array}{l}\text { Duration } \\
\text { (days) }\end{array}$ & $\begin{array}{c}A / V \\
(\mathrm{~mL} / \mathrm{g}) \\
\end{array}$ & $\begin{array}{c}\text { Filtering } \\
(y / n)\end{array}$ & $\begin{array}{l}\text { Cleaning } \\
(\mathrm{V} / \mathrm{n})\end{array}$ \\
\hline 1 & 3 & 5 & $y$ & $y$ \\
\hline 2 & 3 & 5 & $y$ & $n$ \\
\hline 3 & 3 & 5 & $n$ & $y$ \\
\hline 4 & 3 & 5 & $n$ & $n$ \\
\hline 5 & 3 & 10 & $y$ & $y$ \\
\hline 6 & 3 & 10 & y & $n$ \\
\hline 7 & 3 & 10 & n & $y$ \\
\hline 8 & 3 & 10 & $\mathrm{n}$ & $\mathrm{n}$ \\
\hline 9 & 3 & 100 & $y$ & $y$ \\
\hline 10 & 3 & 100 & $y$ & $n$ \\
\hline 11 & 3 & 100 & $n$ & $y$ \\
\hline 12 & 3 & 100 & $n$ & $n$ \\
\hline 13 & 7 & 5 & $y$ & $y$ \\
\hline 14 & 7 & 5 & $y$ & $n$ \\
\hline 15 & 7 & 5 & $n$ & $y$ \\
\hline 16 & 7 & 5 & $\pi$ & $n$ \\
\hline 17 & 7 & 10 & $y$ & $y$ \\
\hline 18 & 7 & 10 & y & $\mathrm{n}$ \\
\hline 19 & 7 & 10 & $n$ & $y$ \\
\hline 20 & 7 & 10 & $n$ & $\mathrm{n}$ \\
\hline 21 & 7 & 100 & $y$ & $y$ \\
\hline 22 & 7 & 100 & $y$ & $\mathrm{n}$ \\
\hline 23 & 7 & 100 & $\mathrm{n}$ & $y$ \\
\hline 24 & 7 & 100 & $n$ & n \\
\hline
\end{tabular}

with in each block were not set up in a random order, but the consequences of this are expected to be small (the set-up steps are not likely to introduce confounding effects). Of more concern is that the leachates within each block required over a day to analyze; calibrations and other within-day and day-to-day changes in the ICP lab can occur in this time frame. Without randomizing the order of leachate analyses, such changes can be confounded with the effects of the factors being investigated. 


\subsection{STATISTICAL ANALYSES OF THE DATA}

The statistical investigations of the data from the PCT experiment focused on the following areas:

- summarizing the means, standard deviations (SDs) and percent relative standard deviations (\%RSDs) of $\mathrm{pH}$ and each elemental release over the three replicates for each combination of glass and PCT conditions

- assessing how $\mathrm{pH}$ and the elemental releases were affected by varying the glass tested and the PCT conditions

- assessing how the precision of $\mathrm{pH}$ and the elemental releases were affected by varying the glass tested and the PCT conditions

- assessing how the ability to discriminate between SRL-202-G and SRL-202-P was affected by varying the PCT conditions.

The first area listed involves calculating some summary statistics, whereas the last three involve making inferences about which of the factors investigated in the experiment have significant effects on the PCT elemental releases, precision, and ability to discriminate between two glasses.

\subsection{MEANS, STANDARD DEVIATIONS, AND \%RSDS}

The raw data ( $\mathrm{pH}$ values and elemental release values) from the $\mathrm{PCT}$ experiment are given in Tables A.1 through A.6 of Appendix A. Using these raw data, the means, SDs, and \%RSDs for $\mathrm{pH}$ and the elemental releases of $\mathrm{A} 1$, $\mathrm{Fe}, \mathrm{K}, \mathrm{Na}, \mathrm{Si}, \mathrm{B}, \mathrm{Li}$, and $\mathrm{Mn}$ were computed and are listed in Table 4.1. These summary statistics are listed for both the SRL-202-G and SRL-202-P glasses for each of the 24 PCT conditions investigated.

In order to interpret the SDs and \%RSDs listed in Table 4.1, it is important that the sources of variation contributing to the results be discussed. The SDs and \%RSDs were computed from the triplicate results, which were obtained at three separate times over the space of $21 / 2$ months. Because of the $21 / 2$-month time span, it is clear that both short-term within-lab and long-term within-lab sources of variation are included in the results. However, not all of the potential sources of variation that affect PCT results were allowed to vary over the three replicate experiments. 
TABLE 4.1. Means, SDs, and \%RSDs from the PCT Experiment on G7asses SRL-202-G and SRL-202-P

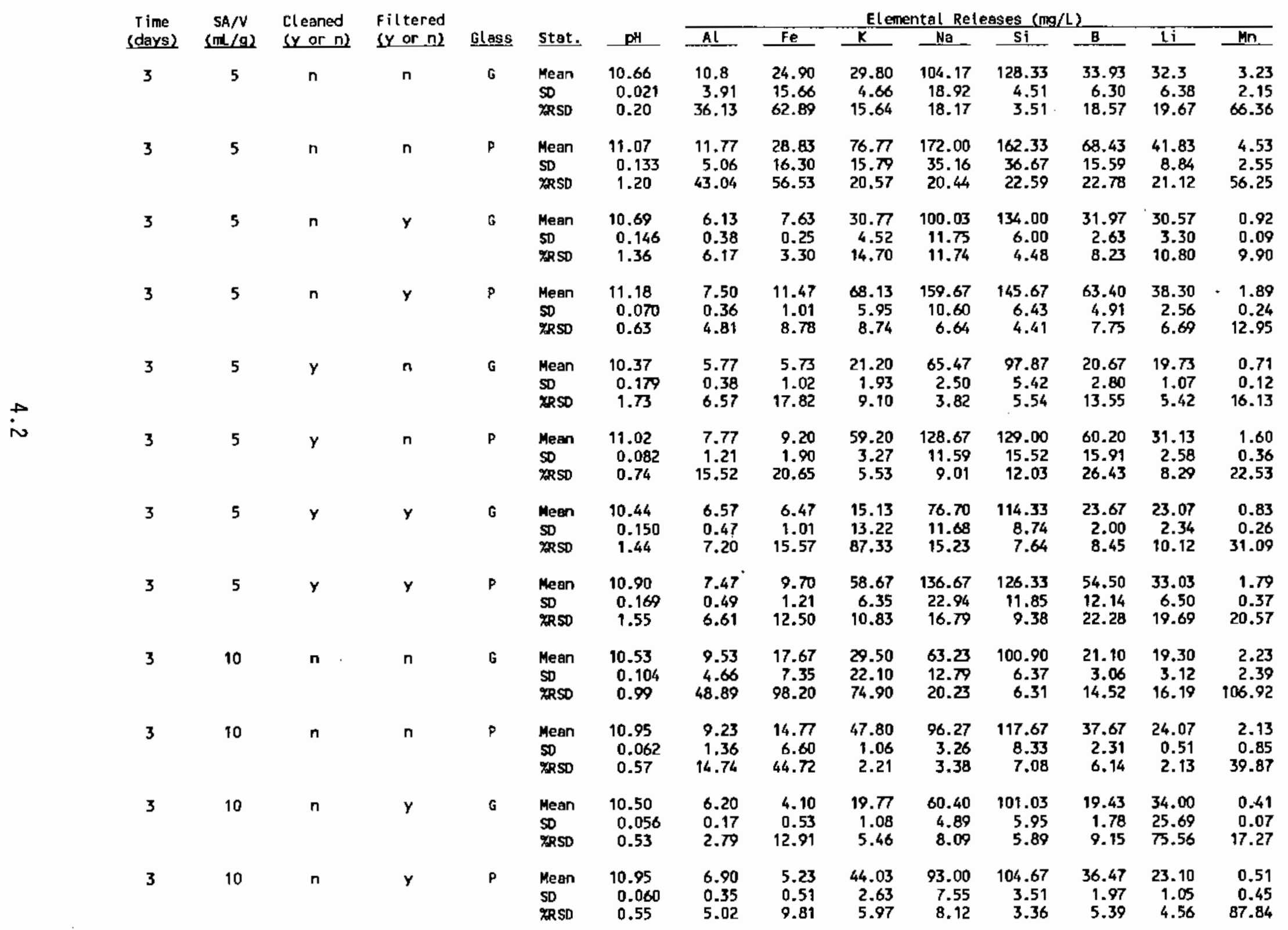


TABLE 4.1. (contd)

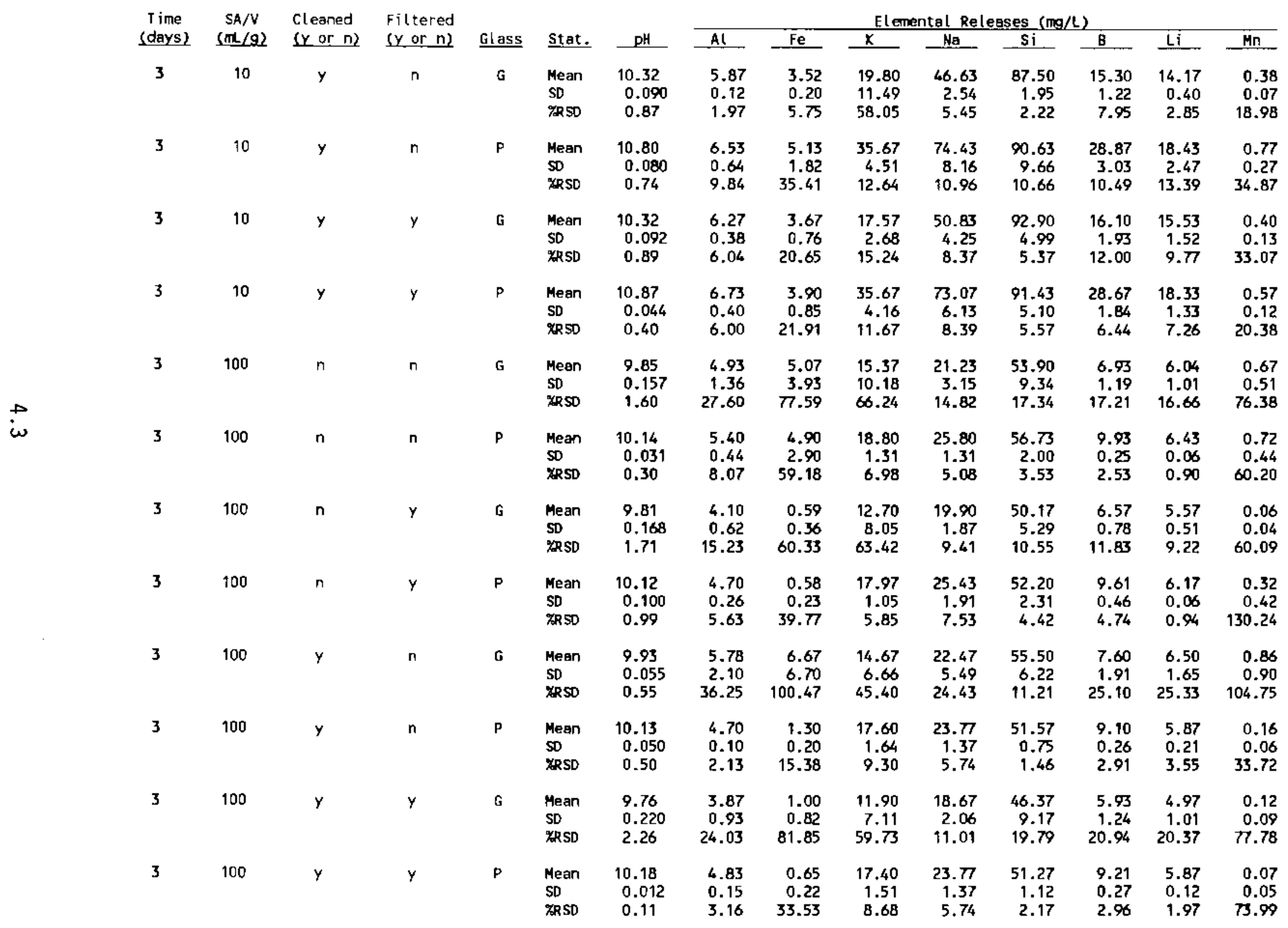


IABLE 4.1. (contd)

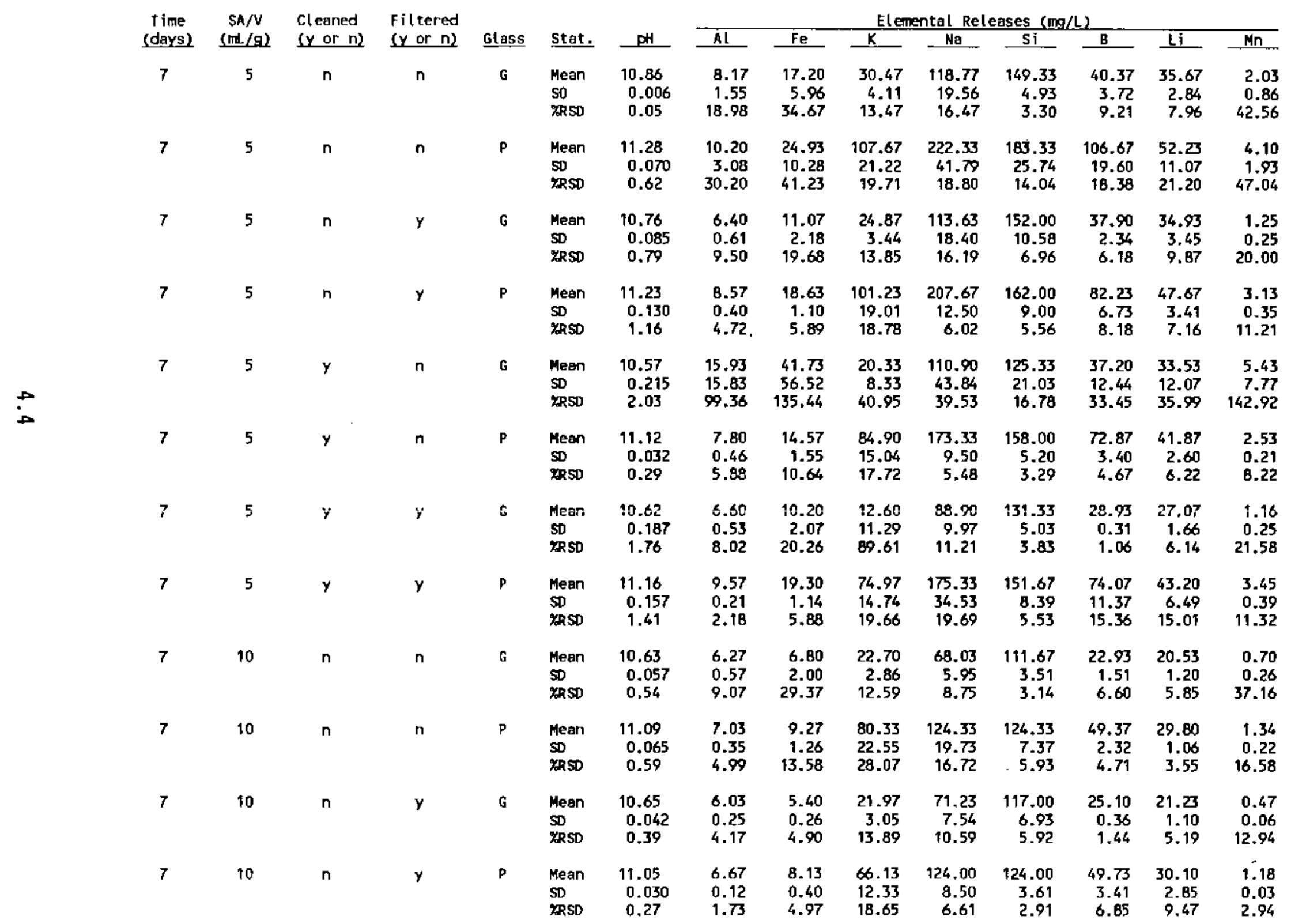


IABLE 4.1. (contd)

\begin{tabular}{|c|c|c|c|c|c|c|c|c|c|c|c|c|c|c|}
\hline Time & SA/N & Cleaned & Fil tered & & & & & & $1 \in \mathbb{1}$ & ntal Rel & eases (mg) & & & \\
\hline (deys) & $(m L / 9)$ & $(y$ or $n)$ & $(y$ or $n)$ & Glass & Stat. & $\mathrm{pH}$ & $\mathrm{Al}$ & $\mathrm{Fe}$ & $k$ & $\mathrm{Na}$ & si & 8 & $\underline{L}$ & $\overline{M n}$ \\
\hline 7 & 10 & $y$ & $n$ & G & $\begin{array}{l}\text { Mean } \\
\text { SD } \\
\text { XRSD }\end{array}$ & $\begin{array}{l}10.51 \\
0.036 \\
0.34\end{array}$ & $\begin{array}{r}19.7 \\
22.57 \\
114.18\end{array}$ & $\begin{array}{r}51.53 \\
76.08 \\
148.79\end{array}$ & $\begin{array}{l}42.13 \\
37.15 \\
88.16\end{array}$ & $\begin{array}{l}90.90 \\
52.41 \\
57.66\end{array}$ & $\begin{array}{r}102.40 \\
5.05 \\
4.93\end{array}$ & $\begin{array}{l}30.33 \\
18.60 \\
61.31\end{array}$ & $\begin{array}{l}26.93 \\
16.08 \\
59.71\end{array}$ & $\begin{array}{r}6.63 \\
10.20 \\
153.89\end{array}$ \\
\hline 7 & 10 & $y$ & $n$ & $\mathbf{p}$ & $\begin{array}{l}\text { Mean } \\
\text { SD } \\
\text { YRSD }\end{array}$ & $\begin{array}{c}10.98 \\
0.085 \\
0.78\end{array}$ & $\begin{array}{r}9.33 \\
4.48 \\
48.02\end{array}$ & $\begin{array}{l}15.87 \\
15.70 \\
98.97\end{array}$ & $\begin{array}{l}\infty 0.83 \\
21.87 \\
35.94\end{array}$ & $\begin{array}{r}104.67 \\
25.54 \\
24.40\end{array}$ & $\begin{array}{r}131.67 \\
33.50 \\
25.44\end{array}$ & $\begin{array}{r}44.43 \\
5.70 \\
12.84\end{array}$ & $\begin{array}{r}27.57 \\
3.84 \\
13.94\end{array}$ & $\begin{array}{r}2.33 \\
2.40 \\
102.71\end{array}$ \\
\hline 7 & 10 & $y$ & $y$ & G & $\begin{array}{l}\text { Mean } \\
\text { SD } \\
\text { YRSD }\end{array}$ & $\begin{array}{c}10.55 \\
0.049 \\
0.47\end{array}$ & $\begin{array}{r}6.70 \\
1.01 \\
15.15\end{array}$ & $\begin{array}{r}4.80 \\
0.87 \\
18.04\end{array}$ & $\begin{array}{r}18.53 \\
1.75 \\
9.43\end{array}$ & $\begin{array}{r}60.90 \\
6.41 \\
10.53\end{array}$ & $\begin{array}{r}112.00 \\
8.00 \\
7.14\end{array}$ & $\begin{array}{r}20.17 \\
2.60 \\
12.91\end{array}$ & $\begin{array}{r}17.97 \\
1.06 \\
5.90\end{array}$ & $\begin{array}{r}0.38 \\
0.08 \\
19.92\end{array}$ \\
\hline 7 & 10 & $y$ & $y$ & $\mathbf{P}$ & $\begin{array}{l}\text { Mean } \\
50 \\
\text { YRSSD }\end{array}$ & $\begin{array}{c}10.98 \\
0.065 \\
0.59\end{array}$ & $\begin{array}{l}6.90 \\
0.40 \\
5.80\end{array}$ & $\begin{array}{l}6.97 \\
0.31 \\
4.39\end{array}$ & $\begin{array}{l}59.53 \\
13.42 \\
22.54\end{array}$ & $\begin{array}{r}108.10 \\
12.64 \\
11.69\end{array}$ & $\begin{array}{r}115.33 \\
9.02 \\
7.82\end{array}$ & $\begin{array}{r}43.10 \\
2.54 \\
5.88\end{array}$ & $\begin{array}{r}26.17 \\
1.76 \\
6.71\end{array}$ & $\begin{array}{r}0.90 \\
0.21 \\
22.70\end{array}$ \\
\hline 7 & 100 & $n$ & $n$ & G & $\begin{array}{l}\text { Meen } \\
\text { SD } \\
\text { YRSD }\end{array}$ & $\begin{array}{l}9.91 \\
0.125 \\
1.26\end{array}$ & $\begin{array}{l}4.97 \\
0.21 \\
4.19\end{array}$ & $\begin{array}{l}3.70 \\
0.26 \\
7.15\end{array}$ & $\begin{array}{r}10.93 \\
1.10 \\
10.07\end{array}$ & $\begin{array}{r}23.23 \\
1.33 \\
5.72\end{array}$ & $\begin{array}{r}62.80 \\
1.31 \\
2.09\end{array}$ & $\begin{array}{l}8.40 \\
0.17 \\
2.06\end{array}$ & $\begin{array}{l}6.90 \\
0.10 \\
1.45\end{array}$ & $\begin{array}{r}0.43 \\
0.06 \\
13.32\end{array}$ \\
\hline 7 & 100 & $n$ & $n$ & $\mathbf{P}$ & $\begin{array}{l}\text { Mean } \\
\text { SD } \\
\text { XRSD }\end{array}$ & $\begin{array}{c}10.08 \\
0.102 \\
1.01\end{array}$ & $\begin{array}{l}5.50 \\
0.20 \\
3.64\end{array}$ & $\begin{array}{r}4.83 \\
0.59 \\
12.12\end{array}$ & $\begin{array}{r}19.60 \\
2.95 \\
15.03\end{array}$ & $\begin{array}{r}29.70 \\
4.11 \\
13.83\end{array}$ & $\begin{array}{r}60.90 \\
2.82 \\
4.62\end{array}$ & $\begin{array}{r}12.20 \\
0.70 \\
5.74\end{array}$ & $\begin{array}{l}7.83 \\
0.35 \\
4.48\end{array}$ & $\begin{array}{r}0.70 \\
0.10 \\
14.24\end{array}$ \\
\hline 7 & 100 & $n$ & $y$ & G & $\begin{array}{l}\text { Mean } \\
\text { SD } \\
\text { XRSD }\end{array}$ & $\begin{array}{l}9.91 \\
0.174 \\
1.76\end{array}$ & $\begin{array}{l}4.87 \\
0.32 \\
6.61\end{array}$ & $\begin{array}{r}1.30 \\
0.20 \\
15.38\end{array}$ & $\begin{array}{r}8.63 \\
7.75 \\
89.80\end{array}$ & $\begin{array}{r}24.77 \\
0.40 \\
1.63\end{array}$ & $\begin{array}{r}64.47 \\
2.16 \\
3.35\end{array}$ & $\begin{array}{l}8.80 \\
0.10 \\
1.14\end{array}$ & $\begin{array}{l}7.23 \\
0.29 \\
3.99\end{array}$ & $\begin{array}{l}0.09 \\
0.01 \\
0.19\end{array}$ \\
\hline 7 & 100 & $n$ & $y$ & $\mathbf{p}$ & $\begin{array}{l}\text { Megn } \\
\text { SD } \\
\text { YRSD }\end{array}$ & $\begin{array}{c}10.07 \\
0.046 \\
0.46\end{array}$ & $\begin{array}{l}5.03 \\
0.35 \\
6.98\end{array}$ & $\begin{array}{r}2.08 \\
1.50 \\
71.85\end{array}$ & $\begin{array}{r}20.60 \\
3.14 \\
15.26\end{array}$ & $\begin{array}{r}28.43 \\
3.88 \\
13.65\end{array}$ & $\begin{array}{r}58.63 \\
2.51 \\
4.28\end{array}$ & $\begin{array}{r}12.07 \\
0.70 \\
5.82\end{array}$ & $\begin{array}{l}7.70 \\
0.40 \\
5.19\end{array}$ & $\begin{array}{r}0.31 \\
0.25 \\
81.80\end{array}$ \\
\hline 7 & 100 & $y$ & $n$ & G & $\begin{array}{l}\text { Mean } \\
\text { SD } \\
\text { XRSD }\end{array}$ & $\begin{array}{l}9.70 \\
0.249 \\
2.57\end{array}$ & $\begin{array}{l}4.83 \\
0.35 \\
7.27\end{array}$ & $\begin{array}{l}4.90 \\
0.30 \\
6.12\end{array}$ & $\begin{array}{r}7.03 \\
6.11 \\
86.84\end{array}$ & $\begin{array}{r}21.20 \\
0.53 \\
2.50\end{array}$ & $\begin{array}{r}59.33 \\
2.52 \\
4.24\end{array}$ & $\begin{array}{l}7.57 \\
0.38 \\
5.00\end{array}$ & $\begin{array}{l}6.30 \\
0.46 \\
7.27\end{array}$ & $\begin{array}{r}0.56 \\
0.10 \\
18.56\end{array}$ \\
\hline 7 & 100 & $y$ & $n$ & $\mathbf{p}$ & $\begin{array}{l}\text { Mean } \\
S D \\
\text { YRSDD }\end{array}$ & $\begin{array}{l}10.01 \\
0.050 \\
0.50\end{array}$ & $\begin{array}{l}4.77 \\
0.12 \\
2.42\end{array}$ & $\begin{array}{r}1.55 \\
0.61 \\
39.19\end{array}$ & $\begin{array}{r}18.03 \\
1.70 \\
9.45\end{array}$ & $\begin{array}{r}26.73 \\
3.10 \\
11.60\end{array}$ & $\begin{array}{r}55.33 \\
0.58 \\
1.04\end{array}$ & $\begin{array}{r}10.93 \\
0.45 \\
4.12\end{array}$ & $\begin{array}{l}7.03 \\
0.25 \\
3.58\end{array}$ & $\begin{array}{r}0.22 \\
0.08 \\
35.25\end{array}$ \\
\hline 7 & 100 & $y$ & $y$ & G & $\begin{array}{l}\text { Mean } \\
\text { SD } \\
\text { YRSDD }\end{array}$ & $\begin{array}{l}9.96 \\
0.104 \\
1.05\end{array}$ & $\begin{array}{l}4.83 \\
0.29 \\
5.97\end{array}$ & $\begin{array}{l}1.13 \\
0.06 \\
5.08\end{array}$ & $\begin{array}{l}9.70 \\
0.61 \\
6.27\end{array}$ & $\begin{array}{r}23.87 \\
1.03 \\
4.30\end{array}$ & $\begin{array}{r}61.30 \\
2.04 \\
3.33\end{array}$ & $\begin{array}{l}8.37 \\
0.25 \\
3.01\end{array}$ & $\begin{array}{l}6.67 \\
0.23 \\
3.46\end{array}$ & $\begin{array}{r}0.08 \\
0.02 \\
21.65\end{array}$ \\
\hline 7 & 100 & $y$ & $y$ & $\mathbf{P}$ & $\begin{array}{l}\text { Mean } \\
\text { SD } \\
\text { YRSD }\end{array}$ & $\begin{array}{c}10.04 \\
0.090 \\
0.89\end{array}$ & $\begin{array}{r}5.00 \\
0.61 \\
12.17\end{array}$ & $\begin{array}{l}0.97 \\
0.06 \\
5.97\end{array}$ & $\begin{array}{l}13.07 \\
11.57 \\
88.53\end{array}$ & $\begin{array}{r}27.23 \\
4.29 \\
15.74\end{array}$ & $\begin{array}{r}58.13 \\
6.18 \\
10.64\end{array}$ & $\begin{array}{r}11.60 \\
1.22 \\
10.49\end{array}$ & $\begin{array}{l}7.27 \\
0.58 \\
7.95\end{array}$ & $\begin{array}{l}0.13 \\
0.01 \\
4.56\end{array}$ \\
\hline
\end{tabular}


The crushing, sieving, and cleaning of the SRL-202-G and SRL-202-P glasses were performed at the same time, prior to the three replicates of the PCT experiment. Because these activities were performed only once and not separately before each of the three replicates of the experiment, the data do not contain any information on the variation in PCT results due to the crushing, sieving, or cleaning steps of the procedure. The crushing and sieving of glass is thought to be a major source of variation in the PCT procedure; therefore the SDs and \%RSDs in Table 4.1 may be substantially less than what they would have been had this source of variation been included in the experimental design.

Table 4.2 lists the minimum, median, and maximum \%RSDs for $\mathrm{pH}$ and each element over the 24 test conditions investigated. It should be kept in mind that the \%RSDs are based on samples of size three, indicating that they are fairly uncertain. Still, it is clear that the precision of the PCT varies both with respect to test conditions and the element of interest, and that the short-term and long-term precision of the PCT can be very large (even with some of the major sources of variation "missing") depending on the test conditions.

\subsection{EFFECTS OF THE EXPERIMENTAL FACTORS ON PH AND ELEMENTAL RELEASES}

The analysis of variance (ANOVA) technique was used to investigate whether $\mathrm{pH}$ and elemental releases depend on the levels of the factors 1 isted in Table 4.3. ANOVA is a statistical technique for determining whether varying the levels of factors affects one or more responses of interest. Factors may affect the responses individually and/or via interactions with other factors.

IABLE 4.2. Minimum, Median, and Maximum \%RSDs Over the 24 Test Conditions Investigated in the PCT Experiment

\begin{tabular}{|c|c|c|c|c|c|c|c|c|c|}
\hline$S D$ & $\mathrm{pH}$ & Al & $\mathrm{Fe}$ & K & $\mathrm{Na}$ & $-\underline{S i}$ & B & $\mathrm{Li}$ & $M n$ \\
\hline$n$ & 0.05 & 1.73 & 3.30 & 2.21 & 1.62 & 1.04 & 1.06 & 0.90 & 2.94 \\
\hline $\mathrm{di}$ & 0.76 & 6.79 & 19.97 & 15.25 & 10.77 & 5.53 & 8.06 & 7.27 & 26.89 \\
\hline & 5 & 114.18 & 148.79 & 89.80 & 57.66 & 25.44 & 61.31 & $75 \quad 56$ & 153.89 \\
\hline
\end{tabular}


TABLE 4.3. Factors on $\mathrm{pH}$ and Elementa7 Releases

\begin{tabular}{|c|c|c|}
\hline Factor & Notation & Levels \\
\hline Replicates & $\mathrm{R}$ & $1,2,3$ \\
\hline Glass & G & SRL-202-G, SRL-202-P \\
\hline Test Duration & $T$ & 3,7 days \\
\hline$A / V$ & $S$ & $5,10,100 \mathrm{~mL} / \mathrm{g}$ \\
\hline Cleaning & C & yes, no \\
\hline Filtering & $\mathrm{F}$ & yes, no \\
\hline
\end{tabular}

All main effects (i.e., effects of individual factors) and two-factor interactions were investigated, as well as the three- and four-factor interactions of the $G, T, S, C$, and $F$ factors. When a k-factor interaction exists, the effect that one of the factors has on $\mathrm{pH}$ or a given elemental release depends on the levels of the other $k-1$ factors involved in the interaction. The main effect of a factor is denoted by its letter notation (e.g., $T$ denotes the effect of changing the duration of the test), while interactions are denoted by joining their letter notations with "*" (e.g., $C^{\star} \mathrm{F}$ denotes the two-factor interaction between the cleaning and filtering factors).

An ANOVA was performed for $\mathrm{pH}$ and each of the eight elemental releases using the GLM procedure in SAS (1985). The results are summarized in Table 4.4. Factors that show up in one or more significant effects (main or interaction) for a given element or $\mathrm{pH}$ are said to have a statistically significant effect on the elemental release or $\mathrm{pH}$ (henceforth, $\mathrm{pH}$ and the eight elemental releases are referred to as "responses").

Several observations can be made from Table 4.4:

- R has a significant main effect for $\mathrm{pH}$ and several elemental releases. This means that the long-term variation in PCT results (regardless of the test conditions) is significantly larger than the short-term variation within a replicate.

- $R * S$ being significant for most of the responses indicates that the differences in results due to the three volume-to-mass (equivalently, surface area-to-volume) ratios varies from replicate to replicate. 
TABLE 4.4. Statistically Significant ${ }^{(a)}$ Factor Effects Found in the ANOVAs Performed on the $\mathrm{pH}$ and Elemental Release Data from the PCT Experiment

\begin{tabular}{|c|c|c|c|c|c|c|c|c|c|}
\hline Effect & $\mathrm{pH}$ & Al & $\underline{\mathrm{Fe}}$ & $\underline{\mathbf{K}}$ & $\underline{\mathrm{Na}}$ & $\underline{s i}$ & $\underline{B}$ & $\underline{\mathrm{Li}}$ & $\underline{M n}$ \\
\hline $\mathbf{R}$ & $x$ & & & $x$ & $x$ & $\mathrm{x}$ & $x$ & 0 & \\
\hline G & $x$ & & & $x$ & $x$ & $x$ & $x$ & $x$ & \\
\hline T & $x$ & & 0 & $x$ & $x$ & $\mathrm{x}$ & $x$ & $x$ & 0 \\
\hline s & $x$ & $x$ & $x$ & $x$ & $x$ & $x$ & $x$ & $x$ & $x$ \\
\hline C & $x$ & & & $x$ & $x$ & $\mathrm{x}$ & $x$ & $\mathrm{x}$ & \\
\hline $\begin{array}{l}F \\
R^{\star} G\end{array}$ & & $x$ & & $x$ & & & $x$ & & $x$ \\
\hline$R^{* \top}$ & & & & & $x$ & $\mathrm{x}$ & & & \\
\hline$R \star S$ & 0 & 0 & 0 & $x$ & $x$ & & $x$ & $x$ & 0 \\
\hline $\begin{array}{l}R^{\star} C \\
R^{\star} F\end{array}$ & & & & & & & & & \\
\hline$G^{*} T$ & & & & $x$ & $\mathrm{x}$ & & $x$ & $x$ & \\
\hline$G * S$ & $x$ & & & $x$ & $x$ & $x$ & $x$ & $x$ & \\
\hline$G^{\star} C$ & 0 & & & $x$ & $x$ & & $x$ & & \\
\hline$G * F$ & & & & & & $x$ & & & \\
\hline$T *$ & $x$ & & & $x$ & $\mathrm{x}$ & $x$ & $x$ & $x$ & \\
\hline $\begin{array}{l}T \star C \\
T \star F\end{array}$ & & $x$ & $x$ & & & & & $x$ & $x$ \\
\hline$S^{\star} C$ & $x$ & & & $x$ & $x$ & $x$ & $x$ & $x$ & \\
\hline $\begin{array}{l}S^{\star} F \\
C^{\star} F\end{array}$ & & & & & & & 0 & & \\
\hline$G * T * S$ & & & & $x$ & 0 & & $x$ & & \\
\hline$G \star T \star C$ & & & & & & & 0 & & \\
\hline$G^{*} T * F$ & & & & & & & & & \\
\hline$G * S * C$ & & & & & & & & & \\
\hline$G * S \star F$ & & & & & & $x$ & & & \\
\hline$G^{\star} C^{\star} F$ & & & & & & & & 0 & \\
\hline$T * S \star C$ & & & & & & & & & \\
\hline$T \star S \star F$ & & & & & & & & & \\
\hline$T \star C \star F$ & $x$ & $x$ & $x$ & & 0 & & & & $y$ \\
\hline 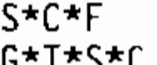 & & & & & & & & & \\
\hline$G * T * S * F$ & & & & & & & & & \\
\hline$G * T * C * F$ & & & & & & & $x$ & & \\
\hline$G \star S * C \star F$ & & & & & & & & & \\
\hline$T \star S \star C * F$ & & & & & & & & & \\
\hline
\end{tabular}

(a) $\begin{aligned} & x=\text { effects significant at the } 95 \% \text { level }(\alpha=0.05) \\ & 0=\text { effects significant at the } 90 \% \text { level }(\alpha=0.10)\end{aligned}$ 
- With one exception (which could be a spurious result due to chance), no four-factor interactions were significant.

- The $T \star C \star F$ three-factor interaction was significant for several of the responses. This indicates that the difference in response between the two levels of any one of the three factors depends on the levels of the other two factors. For example, Figure 4.1 illustrates how filtering affects $\mathrm{Na}$ concentration depending on the test duration and whether the crushed glass was cleaned.

- All six of the factors $R, G, T, S, C$, and $F$ have statistically significant (at the $95 \%$ ievel) effects (either main or interaction) on $\mathrm{pH}, \mathrm{K}, \mathrm{Si}$, and $\mathrm{B}$. This conclusion is based on the results from a 17 data and does not preclude the absence of effects of some factors for certain test conditions, glasses, or replicates.

- All of the factors except $F$ (filtering) have a statistically significant effect (either main or interaction) on Na and Li concentrations. This conclusion is based on the results from all 24 test conditions and does not preclude a filtering effect on $\mathrm{Na}$ and $\mathrm{Li}$ for a few test conditions.

- $G$ is involved in several significant interactions with the test condition variables ( $T, S, C$, and $F$ ) for $K, N a, S i, B$ and $L i$. This indicates that differences between the elemental releases of these elements from SRL-202-G and SRL-202-P depend on the levels of the test condition variables. The ability to discriminate between the glasses may depend on the test conditions, although the precision of each set of test conditions also influences this.

- There is no statistically significant effect of G (i.e., no differences in results between SRL-202-G and SRL-202-P) for AI, Fe, and $\mathrm{Mn}$. This conclusion is based on the results from all 24 test conditions and does not preclude a "glass effect" on Al, Fe, and $\mathrm{Mn}$ concentrations for a few test conditions.

As mentioned in some of the observations above, the conclusions are a sort of "consensus" based on all of the data. Focusing on subsets of the data could lead to different conclusions. 


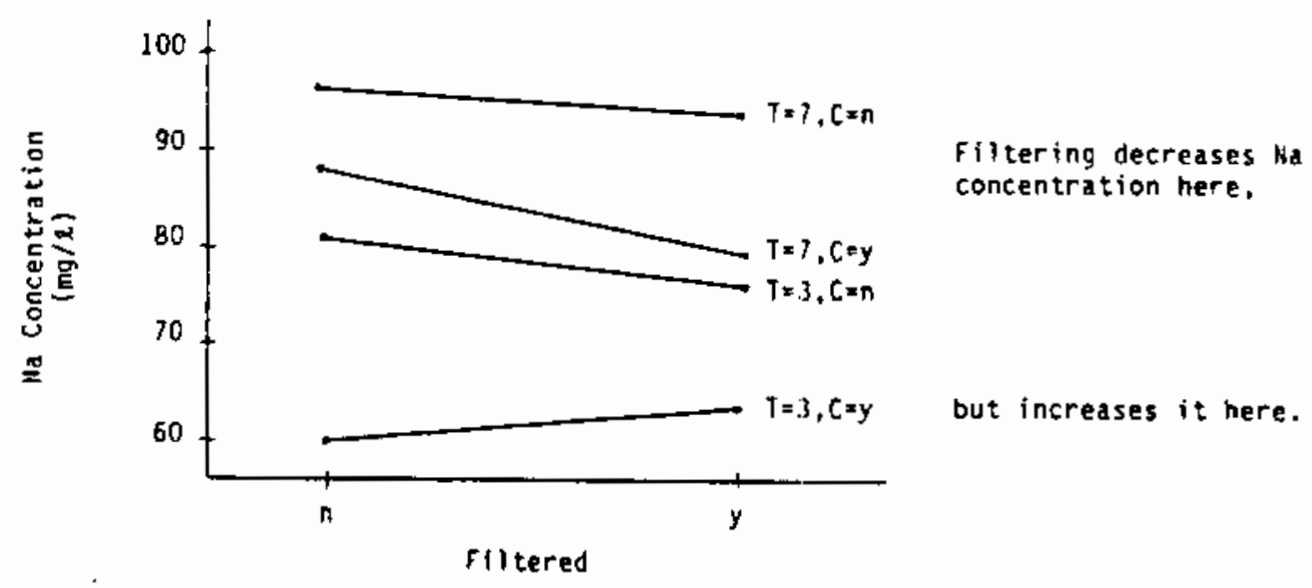

EIGURE 4.1. Illustration of the $T \star C \star F$ Interaction Effect on Na Concentration. The effect of filtering depends on the test duration and whether or not the crushed glass was cleaned.

\subsection{EFFECTS OF THE EXPERIMENTAL FACTORS ON PRECISION}

The ANOVA technique was also used to investigate whether the precision of the $\mathrm{pH}$ and elemental release results depends on the levels of the factors $G, T, S, C$, and $F$. Specifically, ANOVA was performed on the natural logarithms of the variances $(a)$ computed from the three replicate values for each test condition and glass combination. Because the replicate data were required to compute the variances (short-term plus long-term for the sources of variation previously discussed), it was not possible to investigate the effect of replicates (R) or of the four-factor interactions in this ANOVA. The GLM procedure of SAS (1985) was used to perform the ANOVA.

The results of the ANOVA to investigate the factors affecting the precision of the PCT are given in Table 4.5. The following observations are made:

- None of the factors have a statistically significant effect on the precision of the $\mathrm{pH}$ results.

- All of the factors ( $G, T, S, C$, and $F$ ) affect the precision of the $\mathrm{A}], \mathrm{Fe}, \mathrm{Si}, \mathrm{Li}$, and Mn results.

(a) It is common statistical practice to analyze the logarithms of the variances because they tend to more nearly satisfy the normality and constant uncertainty assumptions required for ANOVA. 
TABLE 4.5. Statistically Significant (a) Factor Effects Found in the ANOVAs Performed on Log(Variances) of the $\mathrm{pH}$ and Elemental Release Data from the PCT Experiment

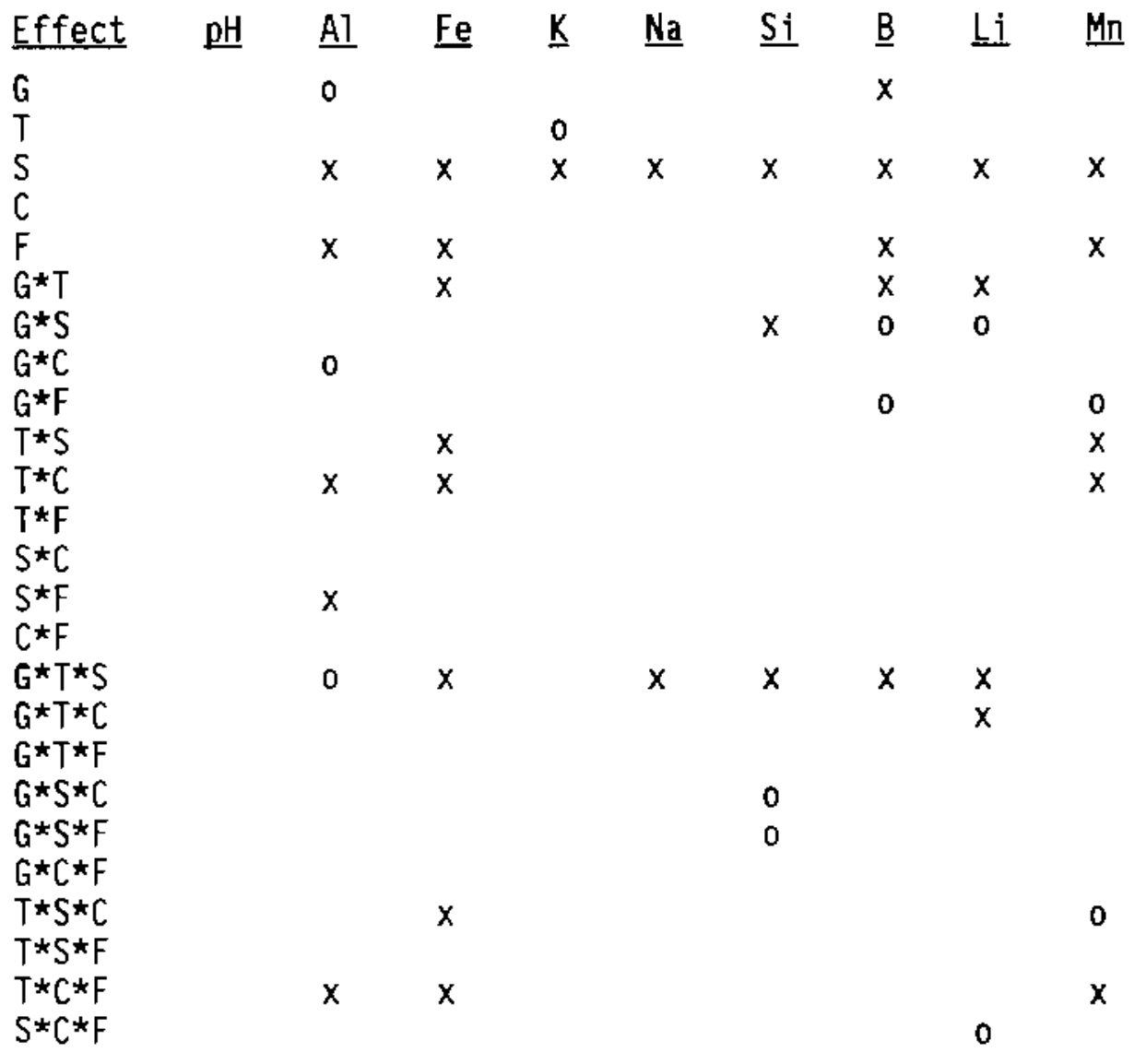

(a) $x=$ effects significant at the $95 \%$ level $(\alpha=0.05)$ $0=$ effects significant at the $90 \%$ Tevel $(\alpha=0.10)$.

- All of the factors except $C$ (cleaning) and $F$ (filtering) affect the precision for $K$ and $\mathrm{Na}$. All of the factors except for $\mathrm{C}$ affect the precision of the $B$ results.

- Factor $S$ has a significant main effect on the precision for all eight elements. The precision increases (i.e., the variance decreases) as the volume/mass ratio increases.

- Factor $F$ has a significant main effect for four elements (Al, Fe, $B$, and $M n$ ). The precision is higher (i.e., the variance is smaller) when the leachate is filtered. Although $F$ is not indicated as having a significant main effect for $K, \mathrm{Na}, \mathrm{Si}$, and $\mathrm{Li}$, the trend is also there for improved precision with filtering. 
These observations are based on ANOVA of the variances for both glasses and for a 1124 sets of test conditions. The observations might differ if attention were focused on subsets of the data.

\subsection{EFFECTS OF THE EXPERIMENTAL FACTORS ON THE ABILITY TO DISCRIMINATE}

The ANOVA technique was also used to investigate whether the ability to discriminate between two glasses based on $\mathrm{pH}$ and elemental releases depends on the levels of the factors $T, S, C$, and $F$. Specifically, ANOVA was performed on t-ratios comparing SRL-202-P and SRL-202-G using the replicate results. T-ratios for $\mathrm{pH}$ and the eight elements were computed according to the formula:

$$
t=\frac{\left(d_{1}+d_{2}+d_{3}\right) / 3}{S D\left(d_{1}, d_{2}, d_{3}\right) / \operatorname{sqrt}(3)}
$$

where $d_{i}=$ the difference in $\mathrm{pH}$ or elemental release values between the SRL-202-G and SRL-202-P glasses for the data from replicate $i$. The value for SRL-202-G is subtracted from the value for SRL-202-P to form $d_{j}$.

The numerator of Equation (4.1) is merely the average of the three $d_{i}$ values, while the denominator is the standard deviation of the three $d_{i}$ values divided by the square root of three. The denominator of Equation (4.1) is the standard deviation of the numerator, and hence Equation (4.1) fits the definitional form for a "t-ratio".

The t-ratios for $\mathrm{pH}$ and the eight elemental releases for each of the 24 sets of test conditions are given in Table 4.6. Note that for a sample of size three, a t-ratio must be larger than 2.92 to discriminate between SRL-202-P and SRL-202-G with 95\% confidence. (a) For pH, Na, B, and (to a iesser extent) $K$, the tratios are larger than 2.92 for most of the 24 sets

(a) The 2.92 critical value corresponds to the 95th percentile of the t-distribution with two degrees of freedom. Since SRL-202-P is a less durable glass than SRL-202-G, it is assumed that only positive t-ratios indicate discrimination between the two glasses. Thus, the t-ratio critical value of 2.92 corresponds to a one-sided t-test. 
TABLE 4.6. T-Ratios (a) for Discriminating Between SRL-202-G and SRL-202-P for Each of 24 Sets of PCT Conditions Investigated in the PCT Experiment

\begin{tabular}{|c|c|c|c|c|c|c|c|c|c|c|c|c|c|c|}
\hline I & $s$ & $\underline{\mathrm{C}}$ & $\underline{\underline{\mathbf{E}}}$ & ph & $\mathrm{Ai}$ & $\mathrm{Fe}$ & K & $\mathrm{Na}$ & $\mathbf{s i}$ & B & $\mathrm{Li}$ & in & $\begin{array}{l}\# t^{\prime} \mathrm{s} \\
>2.92 \\
\end{array}$ & Comments \\
\hline & $\begin{array}{l}5 \\
5\end{array}$ & n & $\begin{array}{l}n \\
y\end{array}$ & $\begin{array}{r}4.69 \\
11.28\end{array}$ & $\begin{array}{r}0.24 \\
41.00\end{array}$ & $\begin{array}{l}0.30 \\
6.00\end{array}$ & $\begin{array}{r}4.21 \\
17.36\end{array}$ & $\begin{array}{r}2.40 \\
68.06\end{array}$ & $\begin{array}{l}1.47 \\
4.85\end{array}$ & $\begin{array}{r}2.96 \\
23.78\end{array}$ & $\begin{array}{r}1.20 \\
17.24\end{array}$ & $\begin{array}{l}0.64 \\
5.67\end{array}$ & $\begin{array}{l}3 \\
9\end{array}$ & \multirow{16}{*}{$\begin{array}{l}\text { Smallest is } 4.85 \text {. } \\
\text { Good. } \\
\text { Smallest is } 4.80 \text {. } \\
\text { Smatlest is } 4.34 \text {. } \\
\text { Smatlest is } 3.36 \text {, } \\
\text { seven are }>8.08 \text {. }\end{array}$} \\
\hline & 5 & $y$ & n & 5.49 & 2.25 & 2.14 & 13.16 & 12.02 & 2.95 & 4.12 & 13.05 & & 7 & \\
\hline & 5 & $y$ & $y$ & 3.27 & 2.56 & 5.11 & 6.15 & 9.19 & 4. & 5.15 & 4.04 & 6.9 & 8 & \\
\hline & $\begin{array}{l}10 \\
10\end{array}$ & $n$ & $n$ & $\begin{array}{l}12.89 \\
15.50\end{array}$ & -0.1 & -0.42 & $\begin{array}{r}1.51 \\
1.02\end{array}$ & 3. & 2. & 5. & 2 & -0 & & \\
\hline & $\begin{array}{l}10 \\
10\end{array}$ & $\begin{array}{l}n \\
y\end{array}$ & $\begin{array}{l}y \\
n\end{array}$ & $\begin{array}{r}15.59 \\
5.64\end{array}$ & $\begin{array}{l}2.65 \\
1.52\end{array}$ & $\begin{array}{l}4.15 \\
1.66\end{array}$ & $\begin{array}{r}11.93 \\
3.22\end{array}$ & & $\begin{array}{l}0.74 \\
0.56\end{array}$ & $\begin{array}{r}11.13 \\
8.10\end{array}$ & $\begin{array}{r}-0.71 \\
2.89\end{array}$ & $\begin{array}{l}5 \\
8\end{array}$ & 5 & \\
\hline & 10 & $y$ & $y$ & 13.61 & 1.24 & 0.67 & 12.36 & 17.11 & -0.90 & 28.75 & 10.58 & & 5 & \\
\hline & 100 & n & n & 3.92 & 0.76 & -0.19 & 0.60 & 3.93 & 0.63 & 4.61 & 0.69 & & 3 & \\
\hline & 100 & $n$ & $y$ & 2.38 & 1.96 & -0.12 & 1.13 & 166.00 & 0.69 & 7.26 & 1.96 & & 1 & \\
\hline & 100 & $y$ & n & 20.00 & -0.86 & -1.42 & 0.73 & 033 & & & -0 . & & 1 & \\
\hline & 100 & $y$ & $y$ & 3.21 & 2.01 & -0.60 & 1.62 & 10.34 & 0.89 & 4.16 & 1.38 & -0 & 3 & \\
\hline & 5 & $n$ & $n$ & 10.39 & 2.05 & 2.93 & 6.15 & 5.74 & 2.08 & 5.10 & 3. & & 7 & \\
\hline & 5 & $\mathbf{n}$ & $y$ & 6.78 & 6.60 & 5.46 & 5.9 & 13.35 & 4.80 & 16.67 & B. & 6. & 9 & \\
\hline & 5 & $y$ & n & 4.86 & -0.89 & -0.83 & 4.8 & & 2.20 & 6. & & -0 . & 4 & \\
\hline & 5 & $y$ & $y$ & 12.77 & 7.90 & 5.01 & 4.34 & 5. & 8.71 & 6.97 . & & & 9 & \\
\hline & 10 & $n$ & $n$ & 39.84 & 1.4 & 1.33 & 4. & & 2.17 & 18. & 11. & & 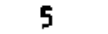 & \\
\hline & 10 & $n$ & $y$ & 28.80 & 3.80 & 8.60 & 8.08 & 101 & 3.36 & 11.37 & & & 9 & \\
\hline & 10 & $y$ & $\mathrm{n}$ & 14.26 & -1.0 & 1 & 2. & 0.8 & 1.42 & 1.88 & 0. & -0 & 1 & \\
\hline & 10 & $y$ & $y$ & 9.38 & 0.42 & 5.64 & 5. & 10.67 & 0.64 & 36.21 & 20. & & 7 & \\
\hline & 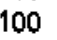 & n & n & 4.23 & 16.00 & 2.88 & 4. & 3.95 & -2.11 & 11.82 & 3 & 4. & 7 & \\
\hline & & $\mathrm{n}$ & $y$ & 1.58 & 1.15 & 0. & 1. & 1.81 & -13.23 & & & & 2 & \\
\hline & & $y$ & 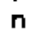 & 2.67 & -0.46 & -6.47 & 2. & 2.64 & -3.46 & & & -3 & 1 & \\
\hline & & & $y$ & 6.93 & 0.90 & $-c .30$ & 0.53 & 1.68 & & & & & & \\
\hline
\end{tabular}

(a) Positive $t$-ratios indicate that the mean $\mathrm{pH}$ or elemental release for SRL-202-P was larger than the corresponding value for SRL-202-G. T-ratios Larger than 2.92 indicate a statistically significant difference.

of test conditions. This indicates that these variables are a good basis for discriminating between SRL-202-G and SRL-202-P regardless of the PCT conditions used. The elements Al, Fe, Si, Li, and Mn have nonsignificant (smaller than 2.92) t-ratios for several of the 24 test conditions, and some of the $t$-ratios are even negative. However, there are some of the 24 test conditions for which even these elements have significant t-ratios.

The results of the ANOVA to investigate the effects of the factors $T, S$, $C$, and $F$ on the t-ratios are given in Table 4.7. Only main effects and twofactor interactions were investigated. A few scattered effects were found to be significant, but there doesn't appear to be much commonality from one response ( $\mathrm{pH}$ or one of the ejght elements) to the next. This may be because the t-ratios are only based on a sample of size three, leading to considerable variation and uncertainty in the values. This variation may have made 
it difficult for the ANOVA to declare significance. It is important to remember that failure to declare an effect significant doesn't mean it isn't, there just may not have been enough evidence to declare it significant.

The results in Table 4.7 do indicate that there are significant main effects of $S$ and $F$ for several responses. The means of the t-ratios for each Tevel of each factor are given in Table 4.8 as an aid to understanding the main effects of the factors. For example, the ability to discriminate appears to be better (for most responses) when $S=5$ or 10 rather than 100 . Similarly, filtering the leachate appears to increase the ability to discriminate. There doesn't appear to be much effect of cleaning on the ability to discriminate except for $\mathrm{pH}, \mathrm{AT}, \mathrm{Fe}$, and $\mathrm{Na}$ where "not cleaning" increases the ability to discriminate. Finally, the test duration does not seem to have a consistent effect across the responses.

\subsection{THE "BEST" SETS OF TEST CONDITIONS FOR THE PCT}

Based on the preceding statistical analyses, it is of interest to select the "best" sets of test conditions for the PCT among the 24 studied in the experiment. Criteria for comparing the 24 sets of test conditions include:

- good separation of $\mathrm{pH}$ and elemental release results for different but similar glasses

- good precision for $\mathrm{pH}$ and elemental releases

- good ability to discriminate between different but similar glasses. The third criterion is actually a combination of the first two.

The results of the ANOVA on the t-ratios (Section 4.4) indicated that volume-to-mass (surface area-to-volume) ratio, filtering, and to some extent cleaning affect the ability of the PCT to discriminate between the SRL-202-G and SRL-202-P glasses. These conclusions are in agreement with the tabulations and comments in the last columns of Table 4.6. The tabulation column in Table 4.6 shows for each of the 24 sets of test conditions the number of nine responses ( $\mathrm{pH}$ and the eight elemental releases) having significant (greater than 2.92) t-ratios. The rationale for this tabulation is that, presumably, test conditions that provide discrimination ability for most or 
TABLE 4.7. Statistically Significant ${ }^{(a)}$ Factor Effects Found in the ANOVAs Performed on t-Ratios of the pH and Elemental Release Data from the PCT Experiment

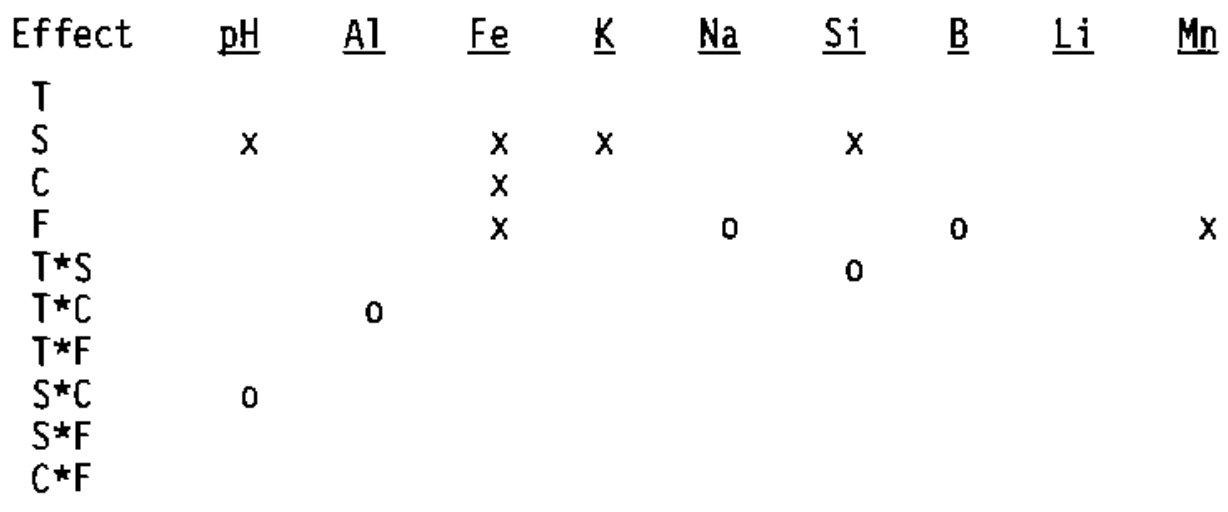

(a) $\begin{aligned} x & =\text { effects significant at the } 95 \% \text { level }(\alpha=0.05) \\ 0 & =\text { effects significant at the } 90 \% \text { leve1 }(\alpha=0.10) .\end{aligned}$

TABLE 4.8. Means of t-Ratios for Each Level of Each Factor

\begin{tabular}{|c|c|c|c|c|c|c|c|c|c|c|}
\hline actor & Level & $\mathrm{pH}$ & $\mathrm{Al}$ & $\mathrm{Fe}$ & K & $\mathrm{Na}$ & $\mathrm{Si}$ & $B$ & $\underline{L i}$ & $\mathrm{Mn}$ \\
\hline $\mathrm{T}$ & $\begin{array}{l}3 \\
7\end{array}$ & $\begin{array}{r}8.5 \\
11.4\end{array}$ & $\begin{array}{l}4.6 \\
3.2\end{array}$ & $\begin{array}{l}1.4 \\
1.8\end{array}$ & $\begin{array}{l}6.2 \\
4.3\end{array}$ & $\begin{array}{l}25.6 \\
13.0\end{array}$ & $\begin{array}{l}1.5 \\
0.4\end{array}$ & $\begin{array}{r}8.9 \\
11.6\end{array}$ & $\begin{array}{l}4.5 \\
6.0\end{array}$ & $\begin{array}{l}1.9 \\
3.8\end{array}$ \\
\hline S & $\begin{array}{r}5 \\
10 \\
100\end{array}$ & $\begin{array}{r}7.4 \\
16.9 \\
5.6\end{array}$ & $\begin{array}{l}7.7 \\
1.2 \\
2.7\end{array}$ & $\begin{array}{r}3.3 \\
2.6 \\
-0.9\end{array}$ & $\begin{array}{l}7.7 \\
6.1 \\
1.7\end{array}$ & $\begin{array}{l}14.9 \\
19.1 \\
23.8\end{array}$ & $\begin{array}{r}4.0 \\
1.3 \\
-2.4\end{array}$ & $\begin{array}{r}8.9 \\
15.1 \\
6.6\end{array}$ & $\begin{array}{l}6.8 \\
7.0 \\
2.0\end{array}$ & $\begin{array}{l}3.4 \\
0.9\end{array}$ \\
\hline c & $\begin{array}{l}n \\
y\end{array}$ & $\begin{array}{r}11.4 \\
8.5\end{array}$ & $\begin{array}{l}6.5 \\
1.3\end{array}$ & $\begin{array}{l}2.6 \\
0.6\end{array}$ & $\begin{array}{l}5.7 \\
4.7\end{array}$ & $\begin{array}{r}31.8 \\
6.8\end{array}$ & $\begin{array}{l}0.6 \\
1.3\end{array}$ & $\begin{array}{r}10.6 \\
9.8\end{array}$ & $\begin{array}{l}5.2 \\
5.3\end{array}$ & $\begin{array}{l}3.4 \\
2.3\end{array}$ \\
\hline$F$ & $\begin{array}{l}n \\
y\end{array}$ & $\begin{array}{r}10.7 \\
9.2\end{array}$ & $\begin{array}{l}1.7 \\
6.0\end{array}$ & $\begin{array}{l}0.1 \\
3.2\end{array}$ & $\begin{array}{l}4.0 \\
6.4\end{array}$ & $\begin{array}{r}4.3 \\
34.2\end{array}$ & $\begin{array}{l}0.8 \\
1.2\end{array}$ & $\begin{array}{r}6.6 \\
13.9\end{array}$ & $\begin{array}{l}3.5 \\
7.0\end{array}$ & 4. \\
\hline
\end{tabular}

a11 of the responses are the best based on the discrimination criterion. Four sets of test conditions had all nine t-ratios significant and one had eight significant: 


\section{Best Discrimination Sets of PCI Conditions}

$\begin{array}{ccccc}I & \underline{S} & \underline{C} & \underline{F} & \begin{array}{l}\text { \#t-ratios } \\ \text { Significant }\end{array} \\ 3 & 5 & n & y & 9 \\ 3 & 5 & y & y & 8 \\ 7 & 5 & n & y & 9 \\ 7 & 5 & y & y & 9 \\ 7 & 10 & n & y & 9\end{array}$

These results are in agreement with those from the ANOVA of t-ratios in that test conditions with smaller volume-to-mass ratios (5 and 10), filtering, and (possibly) no cleaning provide better ability to discriminate between SRL-202-G and SRL-202-P.

It can be verified from Table 4.1 that the five best discrimination sets of conditions shown above have some of the better precisions among the 24 sets of conditions investigated. This should be expected, since t-ratios incorporate precision information. However, it can also be seen from Table 4.1 that other sets of conditions have comparable or even better precisions (e.g., many of the sets of conditions with volume/mass ratios $=100$ ). Because the separation between PCT results from SRL-202-G and SRL-202-P is not as good for these other sets of conditions, they are not "best" from a discrimination standpoint.

Table 4.9 summarizes the \%RSDs for the five best discrimination sets of conditions shown above. This gives an idea of the short-plus long-term precision that can be expected from these test conditions given the sources of variation included. Including the sources of variation due to glass crushing, sieving, and cleaning (which were not included in the PCT experiment) would decrease the precision (increase the \%RSDs). 
IABLE 4.9. \%RSDs Pooled over SRL-202-G and SRL-202-P for the Five Best Discrimination Sets of PCT Conditions

\begin{tabular}{|c|c|c|c|c|c|c|c|c|c|c|c|}
\hline$\underline{S}$ & c & $\underline{F}$ & $\underline{H}$ & A1 & $\mathrm{Fe}$ & K & $\mathrm{Va}$ & $\underline{S i}$ & B & Li & $\mathrm{Mn}$ \\
\hline 5 & $n$ & $y$ & 1.06 & {$[c$} & & & & & & 8 & 11. \\
\hline 5 & $y$ & $y$ & 50 & .91 & & & 3 & 5 & & 65 & \\
\hline 5 & $n$ & $y$ & 9 & 7.50 & & & & & 5 & 12 & 0.2 \\
\hline 5 & $y$ & $y$ & & 5.88 & 14.92 & , & 16. & & 10 & 11.70 & 17.23 \\
\hline & & y & 2 & 3.19 & 94 & c & 8.83 & .8 & .95 & .64 & .3 \\
\hline
\end{tabular}

(a) The value for SRL-202-P is 1isted because the value for SRL-202-G was considerably larger. 



\subsection{CONCLUSIONS}

The main goal of this work was to assess how the ability of the PCT to discriminate between two glasses depends on the levels of several test factors. The ability to discriminate for a given set of test conditions depends on the precision of the test and the "separation" (i.e., difference) in results ( $\mathrm{pH}$ or elemental releases) for the two glasses for the given set of conditions. The sets of test conditions that provide the best ability to discriminate are those that have good precision for the amount of separation produced. Neither good precision nor good separation alone are sufficient to provide good discrimination. Both are important and tradeoffs between the two may be required to achieve good discrimination.

The following conclusions are made relative to separation and precision of the results and the ability of the PCT to discriminate.

- The long-term (replicate-to-replicate) variation in PCT results is significantly larger than the short-term (within replicate) variation for $\mathrm{pH}$ and several elemental releases.

- The effect of $A / V$ (on $\mathrm{pH}$ and most of the elemental releases) varied from replicate to replicate. This indicates that any effort to model PCT responses as a function of $A / V$ should be based on replicate tests conducted at different times.

- In most cases, the $\mathrm{pH}$ and elemental releases depend on the glass tested, the test duration, $A / V$, cleaning, and filtering (i.e., these factors had significant individual or interaction effects for most responses). The exceptions to this are that filtering does not affect $\mathrm{Na}$ and $\mathrm{L} i$, and there are no significant differences between the two glasses for A7, Fe, and Mn.

- The test condition factors (test duration, $A / V$, cleaning, and filtering) displayed significant interactions with "glass" for several responses, indicating that the test factors affect the separation in results between the two glasses.

- The precision of the $\mathrm{pH}$ results was not dependent on the glass tested nor the test condition factors.

- The precision of all elemental releases was affected by the glass tested and the test condition factors with the following exceptions: 1) cleaning did not affect the precision of $B$, and 2) cleaning and filtering did not affect the precision of $\mathrm{K}$ and $\mathrm{Na}$. 
- $A / V$ and filtering had the most significant effects on PCT

precision. The precision increases for all eight elemental releases when leachates are not filtered and as $A / V$ decreases.

These conclusions are based on the results from all 24 sets of test conditions performed on both the SRL-202-G and SRL-203-P glasses and hold for the majority of the data. The conclusions regarding significance or nonsignificance of factor effects may be different for specific subsets of the data. For example, there are a few sets of test conditions for which there is a significant difference between SRL-202-G and SRL-202-P for AT, Fe, and Mn (which is contrary to the third butlet above).

The following conclusions are made regarding the effects of the test condition factors on ability of the PCT to discriminate between SRL-202-G and SRL-202-P.

- The effects of the test condition factors (test duration, $A / V$, cleaning, and filtering) on the ability to discriminate between SRL-202-G and SRL-202-P was investigated using t-ratios computed over the three replicates of the experiment. Only scattered individual and interaction effects of the factors were found to be statistically significant, but this may be due to the small number of replicates.

- It did appear that $A / V$ and filtering have some effect on the ability to discriminate. The ability to discriminate appears to be better for larger A/V values (smaller volume-to-mass ratios) and for tests in which the leachate is filtered. "Not cleaning" test samples may have some effect on ability to discriminate for $\mathrm{pH}, \mathrm{Al}$, $\mathrm{Fe}$, and $\mathrm{Na}$.

- The following five sets of test conditions were identified as providing the best ability to discriminate because they discriminate between SRL-202-G and SRL-202-P for eight or all nine of the responses $(\mathrm{pH}$ and the eight elemental releases):

\begin{tabular}{cccc}
$\begin{array}{c}\text { Test Duration } \\
\text { (days) }\end{array}$ & $\begin{array}{c}A / V \text { in units of } V / m \\
(\mathrm{~mL} / \mathrm{g})\end{array}$ & $\begin{array}{c}\text { Cleaned } \\
(\text { y or } n)\end{array}$ & $\begin{array}{c}0.45 \mu m \\
\text { Filtered } \\
(y \text { or } n)\end{array}$ \\
\cline { 2 - 2 } 3 & 5 & $n$ & $y$ \\
3 & 5 & $y$ & $y$ \\
7 & 5 & $n$ & $y$ \\
7 & 5 & $y$ & $y$
\end{tabular}


- These sets of conditions have some of the better precisions among the sets of conditions considered, but some test conditions with volume/mass ratios $=100 \mathrm{~mL} / \mathrm{g}$ had as good or better precisions. Although the precision for such sets of test conditions was good, the separation of results between SRL-202-G and SRL-202-P was not good, and hence the ability to discriminate was not as good.

Note that these conclusions are specific to discrimination between SRL202-G and SRL-202-P and may or may not hold for other similar glasses. The general effect of high $A / V$ conditions and longer leach times is to increase the total amount of solids dissolved. The dissolution rate usually increases with $A / V$ also. For the same test conditions, a less durable glass would be expected to dissolve faster and yield a higher total solute concentration than a more durable glass. Usually higher total concentrations exhibit greater analytical precision relative to dilute solutions. At high $\mathrm{pH}$ conditions, however, elements such as $\mathrm{Al}, \mathrm{Fe}$, and $\mathrm{Mn}$ tend to form relatively insoluble precipitates or colloids that could control leachate concentrations. Such an effect may have occurred with the two glasses used in this study and could be examined further using geochemical codes. Another problem associated with high $A / V$ systems is that some of the original glass particles can be included with the leachate during the leachate extraction process at the end of a run where the leachate is pipetted into a sample vial. If not filtered, these particles could confuse the results. The use of lower $A / V$ conditions and a focus on alkali elements and $B$, which tend to stay in solution, may avoid some of these types of problems. The effects of very low $\mathrm{A} / \mathrm{V}$ conditions can be investigated using $\mathrm{pH}$-stat methods. Whether or not the results of this study apply to other glasses that may exhibit some of these problems to different degrees is still uncertain and is part of the objective of subsequent work. 



\subsection{REFERENCES}

Jantzen, C. M., and N. E. Bibler. 1987. Product Consistency Test (PCT) for DWPF G1ass; Part I. Test Development and Protocol. DPST-87-575, Savannah River Laboratory, Aiken, South Carolina.

Piepel, G. F., T. E. Jones, D. L. Eggett, and G. B. Mellinger. 1989. Product Consistency Test Round Robin Conducted by the Materials Characterization Center - Summary Report. PNL-6967, Pacific Northwest Laboratory, Richland, Washington.

Montgomery, D. C. 1976. Design and Analysis of Experiments. John Wiley \& Sons, New York.

Pederson, L. R., C. Q. Buckwalter, G. L. McVay, and B. L. Riddle. 1983. "Glass Surface Area to Solution Volume Ratio and Its Implications to Accelerated Leach Testing." Scientific Basis for Nuclear Waste Management, VI, D. G. Brookins (ed.), p. 47-54. North-Holland, New York.

SAS Institute, Inc. 1985. SAS User's Guide: Statistics, Version 5 Edition. SAS Institute, Inc., Cary, North Carolina.

U.S. Department of Energy, Office of Civilian Radioactive Waste Management. 1986. Waste Acceptance Prel iminary Specification for the Defense Waste Processing_Facility High-Level Waste Form. D0E/RW-0125 0GR/B-8, Washington, D.C. 

APPENDIX A

\section{ELEMENTAL RELEASE DATA FOR THE THREE REPLICATES}


IABLE A.1. SRL-202-G, Replicate 1, Deionized Water (DIW), $90^{\circ} \mathrm{C}$

\begin{tabular}{|c|c|c|c|c|c|c|c|c|c|c|c|c|c|}
\hline $\begin{array}{l}\text { Sample } \\
\text { Number }\end{array}$ & $\begin{array}{c}\text { Time } \\
\text { (days) }\end{array}$ & $\begin{array}{c}S A / N \\
(m L / g)\end{array}$ & $\begin{array}{l}\text { Cleened } \\
(y / n)\end{array}$ & $\begin{array}{l}\text { Filtered } \\
(y / n)\end{array}$ & $\mathrm{PH}$ & At & $\mathrm{Fe}$ & K & $\mathrm{Na}$ & $\$ i$ & B & $\mathrm{Li}$ & $\mathrm{Mn}$ \\
\hline $00 \uparrow-g c$ & 3 & 5 & $y$ & $y$ & 10.28 & 6.2 & 5.4 & 24.4 & 68.1 & 107.0 & 21.7 & 21.0 & 0.59 \\
\hline $002-\mathrm{g}$ & 3 & 5 & n & $y$ & 10.79 & 6.4 & 7.4 & 31.3 & 90.1 & 134.0 & 29.6 & 27.3 & 0.82 \\
\hline $003-g c$ & 3 & 5 & $y$ & $n$ & 10.22 & 5.5 & 5.3 & 22.6 & 65.4 & 92.2 & 19.1 & 19.5 & 0.71 \\
\hline $004-9$ & 3 & 5 & n & n & 10.64 & 9.2 & 17.4 & 28.4 & 92.5 & 128.0 & 30.6 & 28.8 & 2.20 \\
\hline $005-\mathrm{gc}$ & 3 & 10 & $y$ & $y$ & 10.40 & 6.0 & 2.8 & 14.7 & 46.5 & 87.2 & 14.0 & 13.9 & 0.25 \\
\hline $006-9$ & 3 & 10 & n & $y$ & 10.51 & 6.0 & 3.5 & 19.3 & 58.2 & 95.1 & 17.5 & 63.6 & 0.34 \\
\hline $007-g c$ & 3 & 10 & $y$ & n & 10.32 & 6.0 & 3.4 & 14.4 & 43.7 & 86.8 & 14.7 & & 0.30 \\
\hline $008-9$ & 3 & 10 & $n$ & $n$ & 10.56 & 7.2 & 7.7 & 17.5 & 56.1 & 95.7 & 18.9 & 97.7 & 0.80 \\
\hline $009-g c$ & 3 & 100 & $y$ & $y$ & 9.54 & 2.8 & 0.1 & 6.7 & 16.3 & 35.8 & 4.5 & 3.8 & 0.02 \\
\hline $010-9$ & 3 & 100 & n & $y$ & 9.66 & 3.4 & 0.2 & 8.1 & 17.8 & 4.2 & 5 & 5.0 & 0.02 \\
\hline $011-g c$ & 3 & 100 & $y$ & $n$ & 9.90 & 8.2 & 14.4 & 13.0 & 28.8 & 62.6 & 9.8 & 8.4 & 1.90 \\
\hline $012 \cdot 9$ & 3 & 100 & $n$ & $n$ & 9.71 & 3.4 & 0.6 & 8.1 & 17.6 & 43.4 & 5.6 & 4.9 & 0.10 \\
\hline $013-9 c$ & 7 & 5 & $y$ & $y$ & 10.76 & 6.4 & B. 5 & 21.8 & 77.4 & 132.0 & 29.0 & 25.3 & 0.90 \\
\hline $014-9$ & 7 & 5 & $n$ & $y$ & 10.77 & 6.1 & 9.3 & 27.6 & 92.9 & 144.0 & 35.2 & 31.2 & 1.00 \\
\hline $015-g c$ & 7 & 5 & $y$ & n & 10.67 & 6.2 & 9.0 & 23.0 & $\pi .7$ & 124.0 & 27 & & 1.00 \\
\hline $016 * 9$ & 7 & 5 & $n$ & $n$ & 10.87 & 6.6 & 11.8 & 29.4 & 96.3 & 146.0 & 36 & 32.6 & 1.30 \\
\hline $017-g c$ & 7 & 10 & $y$ & $y$ & 10.61 & 5.8 & 3.8 & 16.6 & 53.7 & 104.0 & 17.5 & 17.0 & 0.30 \\
\hline $018 \cdot 9$ & 7 & 10 & & $y$ & 10.64 & 5.8 & 5.5 & 18.9 & 62.7 & 109.0 & 25.4 & 20,1 & 0.50 \\
\hline $019-g c$ & 7 & 10 & $y$ & $n$ & 10.55 & & & 19.4 & 54.7 & 98.2 & 17.8 & 16.0 & 0.30 \\
\hline $020-g$ & 7 & 10 & n & $n$ & 10.61 & 6.1 & 6.3 & 21.1 & 62.1 & 108.0 & 21.2 & 19.3 & 0.60 \\
\hline $021-9 c$ & 7 & 100 & $y$ & $y$ & 10.01 & 5.0 & 1.2 & 10.1 & 23.6 & 62.9 & 8.4 & 6.8 & 0.07 \\
\hline $022-g$ & 7 & 100 & n & $y$ & 9.97 & 5.1 & 1.5 & 10.9 & 24.3 & 65.4 & 8. & 7.4 & 0.10 \\
\hline $023-g c$ & 7 & 100 & $y$ & n & 9.89 & 5. & 4. & 10.1 & 21.8 & 62.0 & 8 & 6.8 & 0.50 \\
\hline $024-g$ & 7 & 100 & $n$ & $n$ & 9.90 & 4.8 & 3.6 & 9.8 & 21.7 & 61.4 & 8.2 & 7.0 & 0.40 \\
\hline
\end{tabular}

IABLE A.2. SRL-202-P, Replicate 1, DIW, $90^{\circ} \mathrm{C}$

\begin{tabular}{|c|c|c|c|c|c|c|c|c|c|c|c|c|c|}
\hline $\begin{array}{l}\text { Semple } \\
\text { Nunper }\end{array}$ & $\begin{array}{c}\text { Time } \\
\text { (doys) }\end{array}$ & $\begin{array}{c}\mathrm{SA} / \mathrm{V} \\
(\mathrm{mL} / \mathrm{g})\end{array}$ & $\begin{array}{l}\text { Cleaned } \\
(y / n)\end{array}$ & $\begin{array}{l}\text { Fil tered } \\
(y / n)\end{array}$ & $\mathrm{PH}$ & Al & $\mathrm{Fe}$ & $x$ & $\mathrm{Na}$ & Si & B & $\mathrm{Li}$ & $\mathrm{Mn}$ \\
\hline $001-p c$ & 3 & 5 & $y$ & $y$ & 11.02 & 7.8 & 9.5 & 55.0 & 121.0 & 120.0 & 46.80 & 28.6 & 1.70 \\
\hline $002-p$ & 3 & 5 & n & $y$ & 11.23 & 7.8 & 12.4 & 64.4 & 150.0 & 141.0 & 59.20 & 35.9 & 2.10 \\
\hline $003-p c$ & 3 & 5 & $y$ & n & 11.09 & 7.9 & 8.7 & 55.6 & 127.0 & 128.0 & $\pi .60$ & 30.4 & 1.50 \\
\hline $004-p$ & 3 & 5 & n & n & 11.10 & 6.5 & 11.6 & 67.3 & 158.0 & 135.0 & 61,40 & 37.5 & 2.00 \\
\hline $005-p c$ & 3 & 10 & $y$ & $y$ & 10.92 & 6.5 & 3.1 & 31.0 & 66.2 & 87.0 & 27.10 & 16.8 & 0.50 \\
\hline $006-p$ & 3 & 10 & $n$ & $y$ & 11.01 & 7.1 & 4.8 & 43.1 & 86.0 & 105.0 & 35.70 & 22.1 & 0.00 \\
\hline $007-\mathrm{pc}$ & 3 & 10 & $y$ & $n$ & 10.88 & 5.8 & 3.1 & 31.0 & 65.3 & 79.7 & 25.40 & 45.7 & 0.46 \\
\hline $008-p$ & 3 & 10 & n & $n$ & 11.00 & 9.7 & 14.5 & 47.4 & 94.8 & 127.0 & 38.90 & 24.2 & 2.10 \\
\hline $009-\mathrm{pc}$ & 3 & 100 & $y$ & $y$ & 10.19 & 4.7 & 0.8 & 17.2 & 22.3 & 51.7 & 9.34 & 6.0 & 0.10 \\
\hline $010-p$ & 3 & 100 & $n$ & $y$ & 10.08 & 4.6 & 0.4 & 16.9 & 23.3 & 52.0 & 9.53 & 6.2 & 0.05 \\
\hline $011-p c$ & 3 & 100 & $y$ & n & 10.12 & 4.6 & 1.5 & 15.8 & 22.3 & 50.7 & 8.80 & 5.7 & 0.20 \\
\hline $012-p$ & 3 & 100 & $\pi$ & $n$ & 10.11 & 5.1 & 2.0 & 17.4 & 24.4 & 55.2 & 9.90 & 6.4 & 0.30 \\
\hline $013-p c$ & 7 & 5 & $y$ & $y$ & 11.21 & 0 & 19.8 & 71.9 & 140.0 & 156.0 & 64.40 & 38.9 & 3.25 \\
\hline $014-P$ & 7 & 5 & $n$ & $y$ & 11.10 & 8.1 & 19.5 & 84.7 & 195.0 & 153.0 & 74.80 & 44.1 & 3.50 \\
\hline $015-p c$ & 7 & 5 & $y$ & ח & 11.16 & 8.2 & 16.1 & 73.7 & 164.0 & 161.0 & 69.40 & 39.2 & 2.70 \\
\hline $016-p$ & 7 & 5 & $n$ & n & $\uparrow 1.29$ & 7.9 & 17.2 & 84.0 & 192.0 & 170.0 & 125.00 & 43.9 & 2.70 \\
\hline $017-p c$ & 7 & 10 & $y$ & $y$ & $\uparrow 0.98$ & 6.9 & 6.7 & 52.6 & 97.3 & 116.0 & 41.30 & 24.5 & 0.90 \\
\hline $018-p$ & 7 & 10 & $n$ & $y$ & 11.02 & 6.6 & 8.5 & 56.4 & 119.0 & 120.0 & 46.20 & 27.3 & 1.20 \\
\hline & 7 & 10 & $y$ & $n$ & 11.06 & 7.0 & 6.8 & 46.5 & 80.0 & $\uparrow 17.0$ & 41.60 & 25.2 & 0.90 \\
\hline $020 \cdot P$ & 7 & 10 & $n$ & $n$ & 11.09 & 7.0 & 9.1 & 102.0 & 96.9 & 127.0 & 48.50 & 29.0 & 1.20 \\
\hline $021-p c$ & 7 & 100 & $y$ & $y$ & 10.10 & 5.4 & 0.9 & 17.2 & 23.7 & 61.4 & 12.20 & 7.6 & 0.12 \\
\hline $022+P$ & 7 & 100 & $n$ & $y$ & 10.02 & 5.0 & 9.4 & 17.8 & 24.3 & 58.9 & 12.00 & 7.7 & 0.20 \\
\hline $023-p c$ & 7 & 100 & $y$ & $n$ & 10.06 & 4. & 9.8 & 17.1 & 23.2 & 56.0 & 10.90 & 7.0 & 0.20 \\
\hline $024 \cdot P$ & 7 & 100 & n & $n$ & 10.01 & 5.3 & 5.5 & 17.8 & 25.1 & 57.7 & 11.50 & 7.5 & 0.80 \\
\hline
\end{tabular}


TABLE A.3. SRL-202-G, Replicate 2, DIW, $90^{\circ} \mathrm{C}$

\begin{tabular}{|c|c|c|c|c|c|c|c|c|c|c|c|c|c|}
\hline $\begin{array}{l}\text { Sample } \\
\text { kumber }\end{array}$ & $\begin{array}{c}\text { Time } \\
\text { (days) }\end{array}$ & $\begin{array}{c}S A / N \\
\left(m^{2} / g\right)\end{array}$ & $\begin{array}{l}\text { Cleaned } \\
\langle y / n\rangle\end{array}$ & $\begin{array}{c}\text { Filtered } \\
(y / n) \\
\end{array}$ & $\mathrm{pH}$ & Al & $\mathrm{Fe}$ & $K$ & $\mathrm{Na}$ & si & B & $\mathrm{Li}$ & Mn \\
\hline $101 \cdot \mathrm{gc}$ & 3 & 5 & $y$ & $y$ & 10.45 & 7.1 & 7.4 & 21 & 90.0 & 324.0 & 25.7 & 25.60 & 1.10 \\
\hline $102-g$ & 3 & 5 & $y$ & $y$ & 10.52 & 6.3 & 7.9 & 35 & 113.0 & 140.0 & 34.8 & 33.90 & 1.00 \\
\hline $103-g c$ & 3 & 5 & $y$ & $n$ & 10.33 & 5.6 & 5.0 & 22 & 68.0 & 98.4 & 23.9 & 20.90 & 0.60 \\
\hline $104-g$ & 3 & 5 & $\mathrm{n}$ & $n$ & 10.68 & 8.0 & 14.4 & 26 & 94.0 & 124,0 & 30.0 & 28.70 & 1.80 \\
\hline $105-\mathrm{gc}$ & 3 & 10 & $y$ & $y$ & 10.22 & 6.1 & 4.0 & 18 & 55.0 & 96.5 & 17.8 & 16.90 & 0.50 \\
\hline $106 \cdot g$ & 3 & 10 & $\mathrm{n}$ & $y$ & 10.44 & 6.3 & 4.3 & 19 & 57,0 & 101.0 & 19.8 & & 0.40 \\
\hline $107 \cdot g c$ & 3 & 10 & $y$ & $n$ & 10.23 & 5.8 & 3.4 & 12 & 48.2 & 89.7 & 16.7 & 14.60 & 0.40 \\
\hline $108-9$ & 3 & 10 & 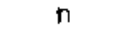 & $n$ & 10.41 & 6.5 & 7.6 & 16 & 55.6 & 99.0 & 19.8 & 17.30 & 0.91 \\
\hline $109-g c$ & 3 & 100 & $y$ & $y$ & 9.98 & 4.5 & 1.2 & 9 & 19.7 & 52.3 & 6.7 & 5.60 & 0.13 \\
\hline $140-\mathrm{g}$ & 3 & 100 & $n$ & $y$ & 9.77 & 4.6 & 0.9 & 8 & 21.4 & 54.3 & 7.2 & 6.00 & 0.09 \\
\hline $111-9 c$ & 3 & 100 & $y$ & $n$ & 9.89 & 4.7 & 2. & 9 & 19.1 & 52.9 & 6.6 & 52.90 & 0.36 \\
\hline $112-\mathrm{g}$ & 3 & 100 & $n$ & $n$ & 9.82 & 6.0 & 8.0 & 11 & 23.1 & 61.3 & 7.9 & 6.81 & 1.09 \\
\hline $113-g c$ & 7 & 5 & $y$ & $y$ & 10.41 & 6.2 & 9.6 & 0 & 94.3 & 126.0 & 29.2 & 28.60 & 1.19 \\
\hline $114-9$ & 7 & 5 & $n$ & $y$ & 10.67 & 6.0 & 10.4 & 26 & 120.0 & 148.0 & 39.1 & 35.60 & 1.25 \\
\hline $1 \uparrow 5-g c$ & 7 & 5 & $y$ & $n$ & 10.32 & 34.2 & 107.0 & 27 & 160.0 & 05.0 & 51.2 & & 14.40 \\
\hline $176-9$ & 7 & 5 & n & $\mathrm{n}$ & 10.86 & 9.7 & 23.6 & 35 & 132.0 & 147.0 & 42.9 & 38.20 & 2.98 \\
\hline $117-g c$ & 7 & 10 & $y$ & $y$ & 30.52 & 6.5 & 5.3 & 20 & 63.0 & 112.0 & 20.3 & 17.80 & 0.45 \\
\hline $118-g$ & 7 & 10 & $\mathrm{n}$ & $y$ & 10.62 & 6.0 & 5. & 22 & 77.0 & 121.0 & 24.7 & 22.30 & 0.51 \\
\hline $119-\mathrm{gc}$ & 7 & 10 & $y$ & $\mathrm{n}$ & 10.50 & 7.8 & 10. & 22 & 67.0 & 108.0 & 21.5 & 19.40 & 1.19 \\
\hline $120-9$ & 7 & 10 & $n$ & $n$ & 10.58 & 6.9 & 9.0 & 21 & 74.0 & 115.0 & 24.0 & 21.70 & 0.99 \\
\hline $12 \uparrow-g c$ & 7 & 100 & $y$ & $y$ & 9.84 & 4.5 & 1.1 & 10 & 23.0 & 59.0 & 8.7 & 6.40 & 0.07 \\
\hline $122-g$ & 7 & 100 & $\mathrm{n}$ & $y$ & 9.71 & 4.5 & 1.1 & 0 & 25.0 & 62.0 & 8.7 & 6.90 & 0.09 \\
\hline $123 \cdot \mathrm{gc}$ & 7 & 100 & $y$ & $n$ & 9.42 & 4. & 5.2 & 0 & 20.8 & 57.0 & 7.3 & 5.90 & 0.68 \\
\hline $124-g$ & 7 & 100 & n & $\mathrm{n}$ & 9.79 & 4 & 4.0 & 11 & 24.0 & 63.0 & 8.5 & 6.80 & 0.50 \\
\hline
\end{tabular}

TABLE A.4. SRL-202-P, Replicate 2, DIW, $90^{\circ} \mathrm{C}$

\begin{tabular}{|c|c|c|c|c|c|c|c|c|c|c|c|c|c|}
\hline $\begin{array}{l}\text { Sample } \\
\text { Number }\end{array}$ & $\begin{array}{c}\text { Time } \\
\text { (days) }\end{array}$ & $\begin{array}{c}S A / N \\
(m L / g)\end{array}$ & $\begin{array}{c}\text { Cleaned } \\
(y / n)\end{array}$ & $\begin{array}{l}\text { Filtered } \\
(y / n)\end{array}$ & $\mathrm{pH}$ & Al & $\mathrm{Fe}$ & $\mathrm{K}$ & $\mathrm{Na}$ & $\mathrm{Si}$ & B & $\underline{\mathrm{Li}}$ & Mn \\
\hline $101-p c$ & 3 & 5 & $y$ & $y$ & 10.71 & 7.7 & $\$ 1,00$ & 66 & 163 & 140.0 & 68.5 & 40.5 & 2.20 \\
\hline $102-p$ & 3 & 5 & $\mathrm{n}$ & $y$ & 11.10 & 7.6 & 11.60 & 75 & 171 & 153.0 & 68.8 & 41.0 & 1.94 \\
\hline $103-p c$ & 3 & 5 & $y$ & n & 10.93 & 8.9 & 91.30 & 60 & 141 & 145.0 & 56.6 & 34.0 & 2.00 \\
\hline $104-p$ & 3 & 5 & $\mathrm{n}$ & $n$ & 10.92 & 16.6 & 44.00 & 95 & 212 & 204.0 & 86.3 & 52.0 & 7.10 \\
\hline $105-p c$ & 3 & 10 & $y$ & $y$ & 10.85 & 7.2 & 4.80 & 39 & 78 & 97.0 & 30.7 & 19.2 & 0.70 \\
\hline $106-p$ & 3 & 10 & $\mathrm{n}$ & $y$ & 10.89 & 7.1 & 5.80 & 47 & 101 & 108.0 & 38.7 & 24.2 & 0.84 \\
\hline $107-p c$ & 3 & 10 & $y$ & $\mathrm{n}$ & 10.80 & 6.8 & 5.70 & 36 & $\pi$ & 94.2 & 30.2 & 19.1 & 0.92 \\
\hline $108-p$ & 3 & 10 & $\mathrm{n}$ & $\mathrm{n}$ & 10.88 & 7.7 & 8.30 & 47 & 100 & 119.0 & 39.1 & 24.5 & 1.30 \\
\hline $109-p c$ & 3 & 100 & $y$ & $y$ & 10.17 & 4.8 & $0 . \overline{5}$ & 16 & 24 & 52.1 & 9.4 & 5.8 & 0.09 \\
\hline$\uparrow 10-p$ & 3 & 100 & $\mathrm{n}$ & $y$ & 10.23 & 5.0 & 0.84 & 19 & 27 & 54.6 & 10.1 & 6.2 & 0.11 \\
\hline $111-p c$ & 3 & 100 & $y$ & $\mathrm{n}$ & 10.08 & 4.8 & 1.30 & 19 & 24 & 52.0 & 9.3 & 5.8 & 0.19 \\
\hline $112-p$ & 3 & 100 & $\mathrm{n}$ & $n$ & 10.13 & 5.9 & 7.80 & 20 & 26 & 59.0 & 10.2 & 6.4 & 1.17 \\
\hline $113-p c$ & 7 & 5 & $y$ & $y$ & 10.98 & 9.8 & 20.10 & 91 & 209 & 142.0 & 86.6 & 50.5 & 3.90 \\
\hline $114-0$ & 7 & 5 & $\mathrm{n}$ & $y$ & 11.22 & 8.8 & 17.40 & 97 & 220 & 162.0 & 87.9 & 50.9 & 2.80 \\
\hline $115-p c$ & 7 & 5 & $y$ & n & 11.10 & 7.9 & 14.60 & $\pi$ & 183 & 161.0 & 76.2 & 44.4 & 2.60 \\
\hline $116-p$ & 7 & 5 & $n$ & $\mathrm{n}$ & 11.21 & 13.7 & 36.60 & 114 & 270 & 213.0 & 109.0 & 64.8 & 6.30 \\
\hline $117-p c$ & 7 & 10 & $y$ & $y$ & 10.92 & 6.5 & 6.90 & 51 & 105 & 106.0 & 42.0 & 26.0 & 1.11 \\
\hline $118-0$ & 7 & 10 & $\mathrm{n}$ & $y$ & 11.05 & 6.8 & 7.70 & 62 & 135 & 127.0 & 53.0 & 33.0 & 1.14 \\
\hline $119-p c$ & 7 & 10 & $y$ & n & 10.90 & 6.5 & 6.80 & 50 & 103 & 108.0 & 40.7 & 25.5 & 1.00 \\
\hline $120-p$ & 7 & 10 & n & $n$ & 11.02 & 6.7 & 8.10 & 57 & 121 & 116.0 & 47.6 & 29.4 & 1.23 \\
\hline $121-p c$ & 7 & 100 & $y$ & $y$ & 9.94 & 4.3 & 1.00 & 22 & 26 & 51.0 & 10.2 & 6.6 & 0.13 \\
\hline $122-p$ & 7 & 100 & n & $y$ & 10.08 & 4.7 & 1.05 & 24 & 29 & 56.0 & 11.4 & 7.3 & 0.13 \\
\hline $123-p c$ & 7 & 100 & $y$ & $n$ & 9.96 & 4.7 & 0.86 & 20 & 29 & 55.0 & 11.4 & 7.3 & 0.15 \\
\hline $124-p$ & 7 & 100 & n & $n$ & 10.04 & 5.5 & 4.60 & 23 & 33 & 62.0 & 12.9 & 8.2 & 0.71 \\
\hline
\end{tabular}


TABLE A.5. SRL-202-G, Rep]icate 3, DIW, $90^{\circ} \mathrm{C}$

\begin{tabular}{|c|c|c|c|c|c|c|c|c|c|c|c|c|c|}
\hline $\begin{array}{l}\text { Sample } \\
\text { Number }\end{array}$ & $\begin{array}{c}\text { Time } \\
\text { (dars) }\end{array}$ & $\begin{array}{c}S A N \\
\left.S \Pi^{L}<g\right)\end{array}$ & $\begin{array}{l}\text { Cleaned } \\
(y / n)\end{array}$ & $\begin{array}{l}\text { Filtered } \\
(y / n)\end{array}$ & 애 & AL & $\mathrm{Fe}$ & $\mathbf{K}$ & $\mathrm{Ma}$ & $\mathrm{Si}$ & B & $\underline{L i}$ & Mn \\
\hline $201-\mathrm{gc}$ & 3 & 5 & $y$ & $y$ & 10.58 & 6.40 & 6.60 & 0 & 72.0 & 112 & 23.6 & 22.6 & 0.79 \\
\hline $202-9$ & 3 & 5 & $r$ & $y$ & 10.75 & $5 . \pi$ & 7.60 & 26 & 97.0 & 128 & 31.5 & 30.5 & 0.93 \\
\hline $203-g c$ & 3 & 5 & $y$ & n & 10.57 & 6.20 & 6.90 & 19 & 63.0 & 103 & 19.0 & 18.8 & 0.83 \\
\hline $204-g$ & 3 & 5 & $\mathrm{n}$ & $n$ & 10.65 & 15.30 & 42.90 & 35 & 126.0 & 133 & 41.2 & 39.8 & 5.70 \\
\hline $205-g c$ & 3 & 10 & $y$ & $y$ & 10.34 & 6.70 & 4.20 & 20 & 51.0 & 95 & 16.5 & 15.8 & 0.45 \\
\hline $206-\mathrm{g}$ & 3 & 10 & $n$ & $y$ & 10.55 & 6.30 & 4.50 & 21 & 66.0 & 107 & 21.0 & 20.9 & 0.48 \\
\hline $207-g c$ & 3 & 10 & $y$ & n & 10.41 & 5.80 & 3.75 & 33 & 48.0 & 86 & 14.5 & 13.8 & 0.44 \\
\hline $208-g$ & 3 & 10 & $\mathrm{n}$ & $n$ & 10.61 & 14.90 & 37.70 & 55 & 78.0 & 108 & 24.6 & 22.9 & 4.99 \\
\hline $209-\mathrm{gc}$ & 3 & 100 & $y$ & $y$ & 9.75 & 4.30 & 1.70 & 20 & 20.0 & 51 & 6.6 & 5. & 0.20 \\
\hline $210-g$ & 3 & 100 & $n$ & $y$ & 9.99 & 4.30 & 0.68 & 22 & 20,5 & 52 & 6 & 5. & 0.07 \\
\hline $211-g c$ & 3 & 100 & $y$ & $n$ & 9.99 & 4.45 & 2.70 & 22 & 19.5 & 51 & 6 & 5 & 0.32 \\
\hline $212-\mathrm{g}$ & 3 & 100 & $n$ & $n$ & 10.02 & 5.40 & 6.60 & 27 & 23.0 & 57 & 7.3 & 6 & 0.82 \\
\hline $213 \cdot g \mathrm{c}$ & 7 & 5 & $\dot{y}$ & $y$ & 10.70 & 7.20 & 92.50 & 16 & 95.0 & 136 & 28.6 & 27 & 1.40 \\
\hline $214-g$ & 7 & 5 & $n$ & $y$ & 10.84 & 7.10 & 13.50 & 21 & 128.0 & 164 & 39.4 & 38 & 1.50 \\
\hline $215-g c$ & 7 & 5 & $y$ & n & 10.71 & 7.40 & 9.20 & 11 & 97.0 & 147 & 33 & 27 & 0.90 \\
\hline $216-9$ & 7 & 5 & n & $n$ & 10.86 & 8.20 & 16.20 & 27 & 128.0 & 155 & 42 & 36 & 1.80 \\
\hline $17-g c$ & 7 & 10 & $y$ & $y$ & 10.53 & 7.80 & 5.30 & 19 & 6.0 & 12 & 22.7 & 18 & 0.40 \\
\hline $218-g$ & 7 & 10 & n & $y$ & 10.70 & 6.30 & 5.10 & 25 & 74.0 & 121 & 25.2 & 21.3 & 0.40 \\
\hline $2 \uparrow 9 \cdot g c$ & 7 & 10 & $y$ & $n$ & 10.48 & 45.80 & 140.00 & 85 & 151.0 & 101 & 51.7 & 45.4 & 18.40 \\
\hline $220-g$ & 7 & 10 & $\mathbf{n}$ & n & 10.69 & 5.80 & 5.10 & 26 & 68.0 & 192 & 23.6 & 20.6 & 0.50 \\
\hline $221-\mathrm{gc}$ & 7 & 100 & $y$ & $y$ & 10.03 & 5.00 & 1.10 & 9 & 25.0 & 62 & 8.6 & 6. & 0.10 \\
\hline $222-\mathrm{g}$ & 7 & 100 & $n$ & $y$ & 10.04 & 5.00 & 3.30 & 15 & 25.0 & 66 & 8 & & 0.09 \\
\hline $3-g c$ & 7 & 100 & $y$ & n & 9.80 & 4.80 & 4.60 & 11 & 21.0 & 59 & 7.4 & 6.2 & 0.50 \\
\hline $224 \cdot \mathrm{g}$ & 7 & 100 & $\mathrm{n}$ & $\mathrm{n}$ & 10.04 & 5.20 & 3.50 & 12 & 24.0 & 64 & 8.5 & 6.9 & 0.40 \\
\hline
\end{tabular}

TABLE A.6. SRL-202-P, Replicate 3, DIW, $90^{\circ} \mathrm{C}$

\begin{tabular}{|c|c|c|c|c|c|c|c|c|c|c|c|c|c|}
\hline $\begin{array}{l}\text { Semple } \\
\text { Number }\end{array}$ & $\begin{array}{c}\text { Time } \\
\text { (days) }\end{array}$ & $\begin{array}{c}S A / N \\
(\mathrm{~mL} / \mathrm{g})\end{array}$ & $\begin{array}{l}\text { Cleaned } \\
(y / n)\end{array}$ & $\begin{array}{l}\text { Filtered } \\
(y / n)\end{array}$ & $\mathrm{pH}$ & $\mathrm{Al}$ & $\mathrm{Fe}$ & K & $\mathrm{Na}$ & si & B & $\underline{\mathrm{Li}}$ & 如 \\
\hline $201-p c$ & 3 & 5 & $y$ & & 10.98 & 6.9 & 8.6 & 55 & 126 & 19.0 & 48.2 & 30.0 & 1.48 \\
\hline $202-p$ & 3 & 5 & n & $y$ & 11.21 & 7.1 & 10.4 & 65 & 158 & 143.0 & 62.2 & 38.0 & 1.62 \\
\hline $203-p c$ & 3 & 5 & $y$ & $n$ & 11.04 & 6.5 & 7.6 & 62 & 118 & 114.0 & 46.4 & 29.0 & 1.30 \\
\hline $204-p$ & 3 & 5 & n & $n$ & 11.18 & 12.2 & 30.9 & 68 & 146 & 148.0 & 57.6 & 36.0 & 4.50 \\
\hline $205-p c$ & 3 & 10 & $y$ & $y$ & 10.84 & 6.5 & 3.8 & 37 & 75 & 90.3 & 28.2 & 19.0 & 0.50 \\
\hline $206-p$ & 3 & 10 & $n$ & $y$ & 10.95 & 6.5 & 5.1 & 42 & 92 & 101.0 & 35.0 & 23.0 & 0.69 \\
\hline $207-p c$ & 3 & 10 & $y$ & $n$ & 10.72 & 7.0 & 6.6 & 40 & 81 & 98.0 & 31.0 & 20.5 & 0.93 \\
\hline $208-p$ & 3 & 10 & $n$ & $n$ & 10.97 & 10.3 & 21.5 & 49 & 94 & 115.0 & 35.0 & 23.5 & 3.00 \\
\hline $209-p c$ & 3 & 100 & $y$ & $y$ & 10.19 & 5.0 & 0.4 & 19 & 25 & 50.0 & 8.9 & 5.8 & 0.01 \\
\hline $210-p$ & 3 & 100 & $y$ & $y$ & 10.04 & 4.5 & 0.5 & 18 & 26 & 50.0 & 9.2 & 6.1 & 0.80 \\
\hline $211-p c$ & 3 & 100 & $y$ & $n$ & 10.18 & 4.7 & 1.1 & 18 & 25 & 52.0 & 9.2 & 6.1 & 0.10 \\
\hline $212-p$ & 3 & 100 & n & $n$ & 10.17 & 5.2 & 4.9 & 19 & 27 & 56.0 & 9.7 & 6.5 & 0.70 \\
\hline $213-p c$ & 7 & 5 & $y$ & $y$ & 11.28 & 9.5 & 18.0 & 62 & 177 & 157.0 & 71.2 & 41.0 & 3.20 \\
\hline $214-p$ & 7 & 5 & n & $y$ & 11.36 & 8.8 & 19.0 & 122 & 208 & 171.0 & 84.0 & 48.0 & 3.10 \\
\hline $215-p c$ & 7 & 5 & $y$ & $n$ & 11.91 & 7.3 & 13.0 & 102 & 173 & 152.0 & 73.0 & 42.0 & 2.30 \\
\hline $216-p$ & 7 & 5 & $n$ & $n$ & 11.35 & 9.0 & 21.0 & 125 & 205 & 167.0 & 86.0 & 48.0 & 3.30 \\
\hline $217-p c$ & 7 & 10 & $y$ & $y$ & 11.05 & 7.3 & 7.3 & $\pi$ & 122 & 124.0 & 46.0 & 28.0 & 0.70 \\
\hline $218-p$ & 7 & 10 & $n$ & $y$ & 11.08 & 6.6 & 8.2 & 80 & 132 & 125.0 & 50.0 & 30.0 & 1.20 \\
\hline 219-pc & 7 & 10 & $y$ & ก & 10.93 & 14.5 & 34.0 & 86 & 131 & 170.0 & 51.0 & 32.0 & 5.10 \\
\hline $220-p$ & 7 & 10 & $n$ & $n$ & 11.15 & 7.4 & 10.6 & 82 & 136 & 130.0 & 52.0 & 31.0 & 1.60 \\
\hline $221-p c$ & 7 & 100 & $y$ & $y$ & 10.09 & 5.3 & 1.0 & 0 & 32 & 62.0 & 12.4 & 7.6 & 0.13 \\
\hline $222-p$ & 7 & 100 & $n$ & $y$ & 70.11 & 5.4 & 3.8 & 20 & 3 & 61.0 & 12.8 & 8.7 & 0.60 \\
\hline $223-p c$ & 7 & 100 & $y$ & $\mathrm{n}$ & 10.02 & 4.7 & 2.0 & 17 & 28 & 55.0 & 10.5 & 6.8 & 0.30 \\
\hline $224-p$ & 7 & 100 & n & n & 10.20 & 5.7 & 4.4 & 18 & 31 & 63.0 & 12.2 & 7.8 & 0.60 \\
\hline
\end{tabular}



APPENDIX B

SUPPLEMENTARY 5 DAY AND 18A DATA FOR SRL-202-G AND SRL-202-P GLASS 
TABLE B.1. Supplemental Table, SRL-202-G and SRL-202-P, Deionized Water, $90^{\circ} \mathrm{C}$

\begin{tabular}{|c|c|c|c|c|c|c|c|c|c|c|c|c|c|}
\hline $\begin{array}{l}\text { Sermple } \\
\text { Number }\end{array}$ & $\begin{array}{c}\text { Time } \\
\text { (deys) }\end{array}$ & $\begin{array}{c}S A / N \\
(\mathbb{K L} / \mathrm{g})\end{array}$ & $\begin{array}{l}\text { Cleaned } \\
(y / n)\end{array}$ & $\begin{array}{l}\text { Filtered } \\
(y / n) \\
\end{array}$ & $\mathrm{pH}$ & AL & $\underline{\mathrm{Fe}}$ & $\underline{\mathbf{K}}$ & 보 & $\underline{\mathbf{S i}}$ & B & $\underline{L i}$ & Mn \\
\hline $\begin{array}{l}\text { srl025gc18 } \\
\text { srl026g18 } \\
\text { srl025pc18 } \\
\text { srl026p18 } \\
\text { srl027gc } \\
\text { srlo28g } \\
\text { srl } 1027 p c \\
\text { srlo28p }\end{array}$ & $\begin{array}{l}7 \\
7 \\
7 \\
7 \\
5 \\
5 \\
5 \\
5\end{array}$ & $\begin{array}{r}5 \\
5 \\
5 \\
5 \\
10 \\
10 \\
10 \\
10\end{array}$ & $\begin{array}{l}y \\
n \\
y \\
n \\
y \\
n \\
y \\
n\end{array}$ & $\begin{array}{r}18 \mathrm{~A} \\
18 \mathrm{~A} \\
18 \mathrm{~A} \\
18 \mathrm{~A} \\
y \\
y \\
y \\
y\end{array}$ & $\begin{array}{l}10.40 \\
10.88 \\
11.28 \\
11.37 \\
10.37 \\
10.60 \\
10.98 \\
11.09\end{array}$ & $\begin{array}{l}2.8 \\
3.3 \\
2.8 \\
3.2 \\
4.9 \\
5.6 \\
6.8 \\
6.8\end{array}$ & $\begin{array}{l}0.0 \\
0.2 \\
0.0 \\
0.0 \\
3.2 \\
4.7 \\
4.5 \\
6.3\end{array}$ & $\begin{array}{r}12 \\
21 \\
39 \\
61 \\
18 \\
0 \\
42 \\
50\end{array}$ & $\begin{array}{r}65 \\
95 \\
112 \\
147 \\
46 \\
69 \\
92 \\
118\end{array}$ & $\begin{array}{r}80 \\
121 \\
94 \\
132 \\
80 \\
107 \\
105 \\
122\end{array}$ & $\begin{array}{l}20.5 \\
30.5 \\
42.0 \\
63.0 \\
13.5 \\
21.0 \\
35.0 \\
46.0\end{array}$ & $\begin{array}{l}19.4 \\
27.0 \\
23.0 \\
34.0 \\
13.2 \\
19.9 \\
21.0 \\
27.0\end{array}$ & $\begin{array}{l}0.0 \\
0.0 \\
0.0 \\
0.0 \\
0.3 \\
0.5 \\
0.6 \\
0.9\end{array}$ \\
\hline
\end{tabular}



PNL -7530

UC -602

\section{DISTRIBUTION}

1. of

pies

:SITE

12 DOE Office of Scientific and Technical Information

A. I. Berusch

DOE Headquarters

Forestall B1dg.

$\mathrm{RW}-231$

Washington, DC 20585

J. A. Coleman

DOE Headquarters

$\mathrm{NE}-25$

Washington, DC 20545

K. Chacey

DOE Headquarters

Washington, DC 20545

G. H. Daly

DOE Headquarters

Washington, DC 20555

T. W. Mcintosh

DOE Headquarters

Washington, DC 20545

M. J. Bell

Nuclear Regulatory Commission

Washington, DC 20555

E. Wicks

Nuclear Regulatory Commission

Washington, DC 20555

H.P.R. Frederikse

U.S. Department of Commerce

National Institute of Science and Technology

Washington, DC 20234
No. of

Copies

A. C. Fracker

U.S. Department of Commerce

National Institute of Science and Technology

Washington, DC 20234

W. P. Reed

Office of Measurements for Nuclear Technology

National Institute of Science and Technology

Physics Building, Room B320

washington, DC 20234

C. G. Interrante

Corrosion Group, Metallurgy Division

National Institute of Science and Technology

MATLS B-254

Gaithersburg, MD 20899

R. Clayton

Enrico Fermi Institute

5640 S. Ell is

Chicago, IL 60647

J. Van Cleve

DOE Oak Ridge Operations office

P.0. Box X

Oak Ridge, TN 37830

W. J. Brumley

DOE Savannah River Operations Office

P. 0. Box A

Aiken, SC 29801

J. C. Haugen

DOE Chicago Operations Office

9800 South Cass Avenue

Argonne, IL 60439 
No. of

Copies

M. D. Valentine

DOE Nevada Operations Office

P.0. Box 1400

Las Vegas, NV 89114

J. K. Bates

Argonne National Laboratory

9700 South Cass Avenue

Argonne, IL 60439

S. Vogler

Argonne National Laboratory

9700 South Cass Avenue

Argonne, IL 60439

Technical Library

Battelle Columbus Division

505 King Avenue

Columbus, $\mathrm{OH} \quad 43201$

P. Colombo

Brookhaven National Laboratory Upton, NY 11973

M. L. Plodinec

Westinghouse Savannah River Company

Savannah River Laboratory

Aiken, SC 29808-0001

G. G. Wicks

Westinghouse Savannah River Company

Savannah River Laboratory

Aiken, SC 29808-000]

C. M. Jantzen

Westinghouse Savannah River Company

Savannah River Laboratory

Aiken, SC 29808-0001

N. E. Bibler

Westinghouse Savannah River Company

Savannah River Laboratory

Aiken, SC 29808-0001
No. of

Copies.

F. M. Neilson, Jr.

$E G \& G$

F.0. Box 1625

Idaho Falls, ID 83415

F. Bazan

Lawrence Livermore National Laboratory

University of California

F.0. Box 808

Livermore, CA 94550

C. Isherwood

Lawrence Livermore National Laboratory

University of $\mathrm{Ca}$ iffornia

P.0. Box 808

Livermore, CA 94550

J. E. Harrar

Lawrence Livermore Nationa] Laboratory

University of California

P.0. Box 808

Livermore, CA 94550

L. Ballou

Lawrence Livermore National Laboratory

University of $\mathrm{Cal}$ ifornia

P.0. Box 808

Livermore, CA 94550

R. D. Mccright

Lawrence Livermore National Laboratory

University of California

P.0. Box 808

Livermore, CA 94550

W. Bourcier

Lawrence Livermore National Laboratory

University of California

P.0. Box 808

Livermore, CA 94550 
No. of

Copies

H. W. Godbee

Oak Ridge National Laboratory

P.0. BoX Y

Oak Ridge, TN 37830

L. R. Dole

Oak Ridge National Laboratory

P.0. Box $X$

Oak Ridge, TN 37830

L. Brush

Sandia National Laboratory

P.0. Box 5800

A1buquerque, NM 87107

M. Magnani

Sandia National Laboratory

P.0. Box 5800

A1buquerque, NM 87107

M. A. Molecke

Sandia National Laboratory

P.0. Box 5800

Albuquerque, NM 87107

P. B. Macedo

Vitreous State Laboratory

Keane $\mathrm{Ha}$ l]

Catholic University of America

Washington, DC 20064

D. A. Clark

University of Florida

Department of Material Science and Engineering

College of Engineering

Gainesville, FL 32611

H. Birnbaum

308 Metallurgy

University of 111 inois

Urbana, IL 61801

W. Walding

Laboratory Services

Corning Glass Works

Houghton Park

Corning, NY 14831
No. of

Copies

A. Lerman

Department of Geologic Science Northwestern University

Evanston, IL 60201

R. L. Coble

Massachusetts institute of Technology

B1dg. 13, Room 4062

77 Massachusetts Avenue

Cambridge, MA 01239

W. W. Gerberich

Dept. of Chemical Engineering and Materials Science

151 Amundson Hall

University of Minnesota

Minneapolis, MN 55455

W. B. White

Pennsylvania State University University Park, PA 16802

A. Barkatt

Vitreous State Laboratory

Keane Hall

Catholic University of America

Washington, DC 20064

H. Barnes

Pennsylvania State University University Park, PA 16802

S. M. Barnes

West Valley Nuclear Services

Co., Inc.

P.0. Box 191

West Valley, NY 14171-0191

J. E. Burke

33 Forest Road

Burnt Hills, NY 12027

S. Clayton

National Energy Information Center

3500 Central Avenue, S.E.

Albuquerque, NM 87131 
No, of

Copies

R. A. Palmer

West Valley Nuclear Services

Co., Inc.

P.O. Box 191

West Valley, NY 14171-0191

G. Maczura

Alcoa Laboratories

Alcoa Technical Center

A]coa Center, PA 15069

\section{ONSITE}

5 DOE Richland operations office

E. A. Bracken, A6-95

S. K. Moy, A6-80

J. R. Hunter, A6-55

R. D. Izatt, $A 6-95$

D. C. Langstaff, A5-90

10 Westinghouse Hanford Company
J. W. Cammann, H4-54
M. H. Campbe11, A4-90
R. P. Colburn, G6-08
K. R. Fecht, H4-56
R. L. Gibby, G6-08
E. H. Randklev, G6-08
S. C. Schaus, A4-90
J. C. Sonnichsen, H4-54
E. T. Weber, G6-08
D. D. Wodrich, R2-23

J. L. Danie1, P8-01

C. L. Eggett, K1-86

R. E. Einziger, $P 7-14$

T. E. Jones, P7-22

N. R. Kreiter, K6-35

B. P. McGrai1, K2-38

G. B. Mellinger, P7-18

J. E. Mendel, P7-18

B. L. Neth, P7-18

K. M. 01son, P7-14

K. A. Parnel1, P7-18

G. F. Piepel, Kl-86 (5)

B. A. Pulsipher, K1-86

W. A. Ross, P7-41

J. W. Shade, P8-37 (10)

S. C. Slate, K6-27

H. D. Smith, P7-14

Publishing Coordination Technical Report Files 